\title{
Miswanting: Some Problems in the Forecasting of Future Affective States
}

\section{Citation}

Gilbert, D. T., \& Wilson, Timothy D. "Miswanting: Some problems in the forecasting of future affective states." In Thinking and feeling: The role of affect in social cognition, edited by Joseph P. Forgas, 178-197. Cambridge: Cambridge University Press, 2000.

\section{Permanent link}

http://nrs.harvard.edu/urn-3:HUL.InstRepos:14549983

\section{Terms of Use}

This article was downloaded from Harvard University's DASH repository, and is made available under the terms and conditions applicable to Other Posted Material, as set forth at http:// nrs.harvard.edu/urn-3:HUL.InstRepos:dash.current.terms-of-use\#LAA

\section{Share Your Story}

The Harvard community has made this article openly available.

Please share how this access benefits you. Submit a story.

Accessibility 


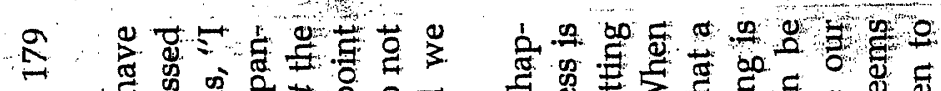

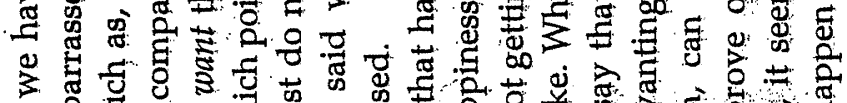
了。

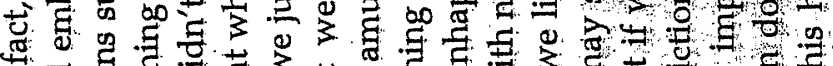

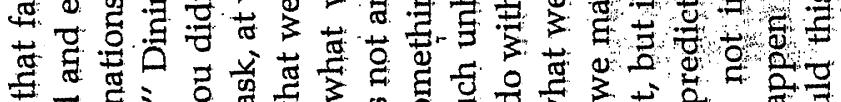

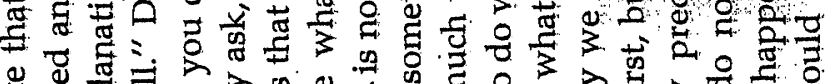

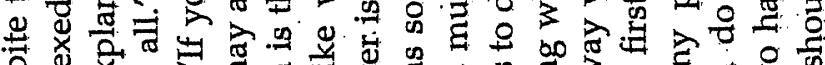

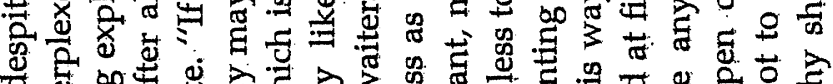

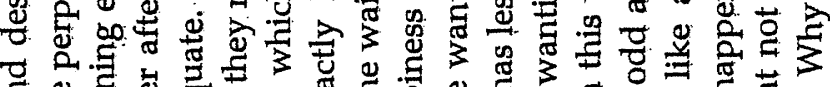

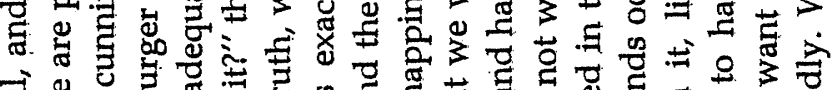

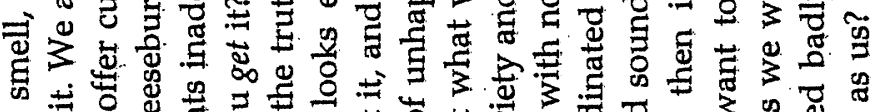
प्र:

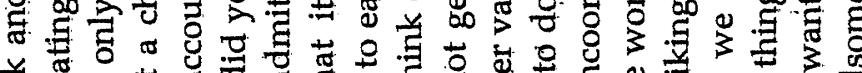
若

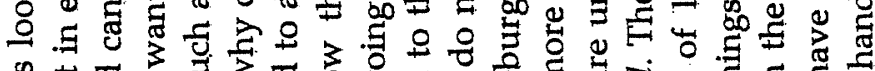

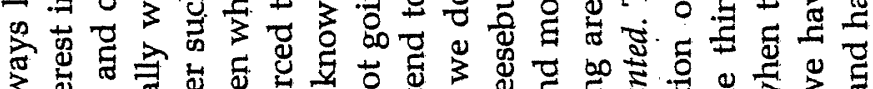

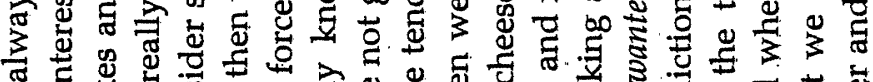

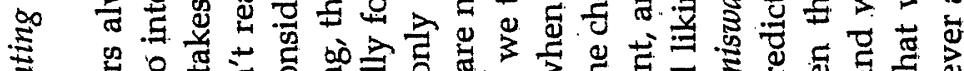

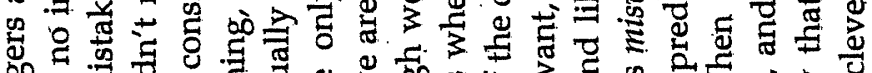

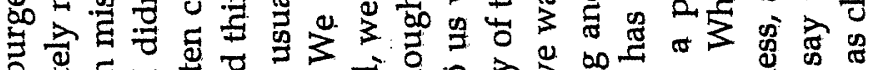

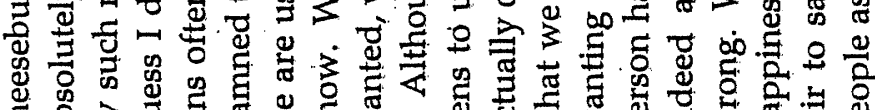

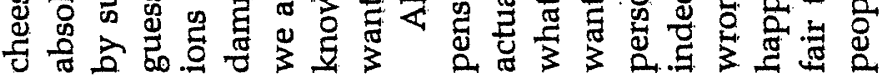

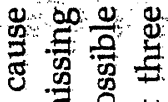

들 䔽

:

30.

or $z$

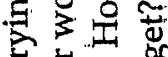

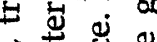

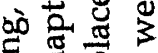

娄

象专 $\frac{\pi}{3}$

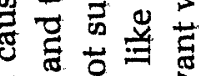

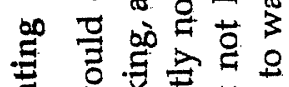

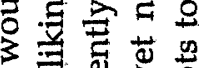

$00 \%$ 吾

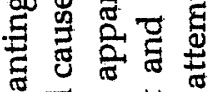

可.

万人 क

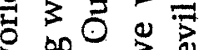

3303

过

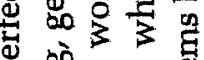

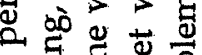

त

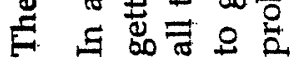

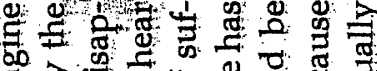

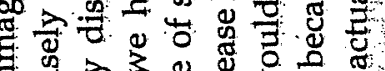

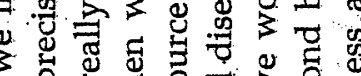

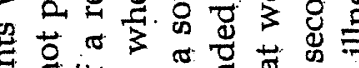

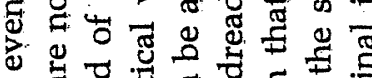

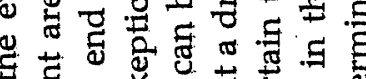

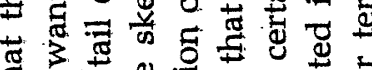

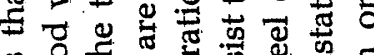

.7 용

(

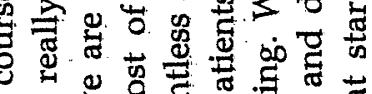

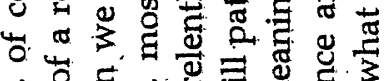

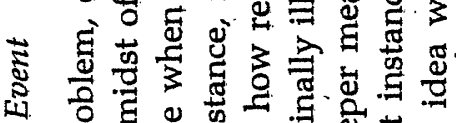

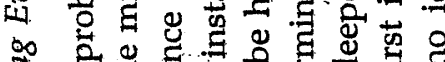

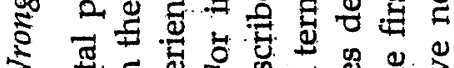

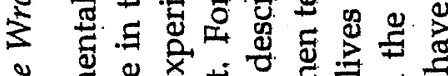

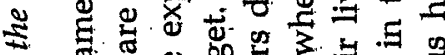

$\infty$ \%

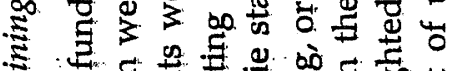

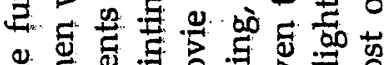

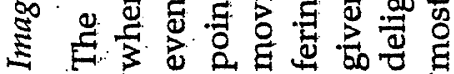

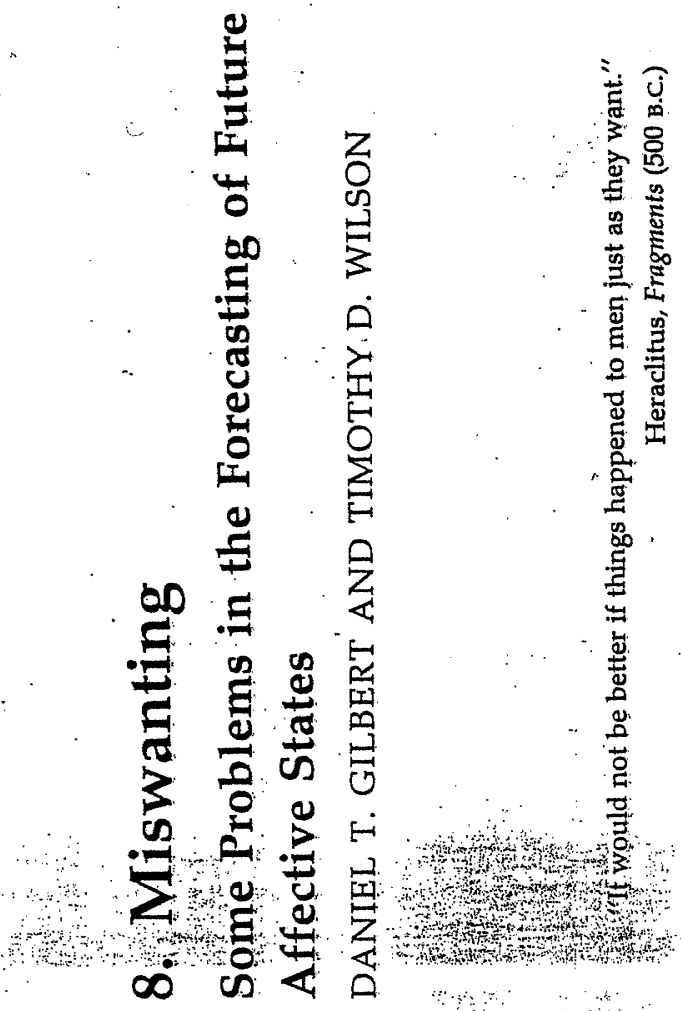

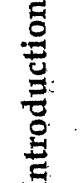

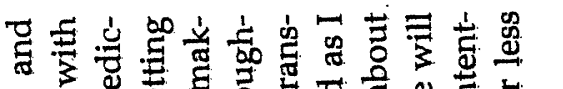

人。

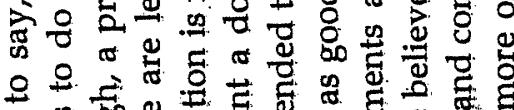

द g

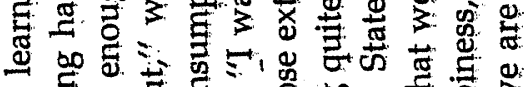

들

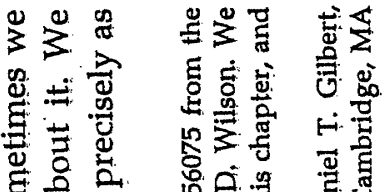

है के क्षे

2

돌

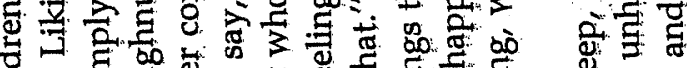

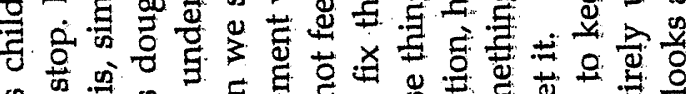

क क .

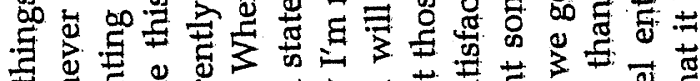

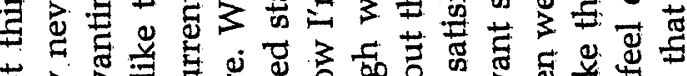

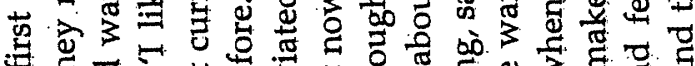

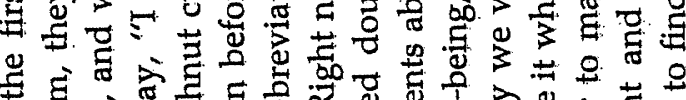

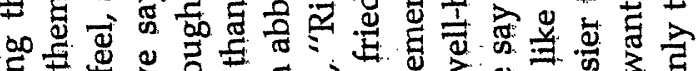

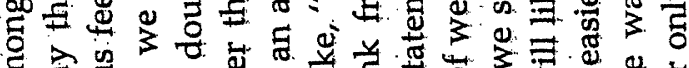

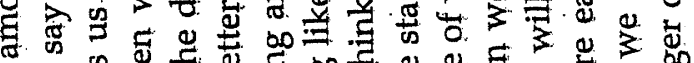
.

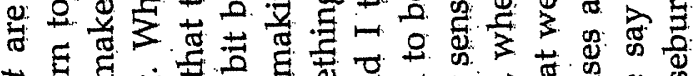

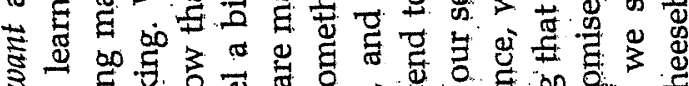

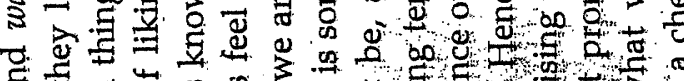

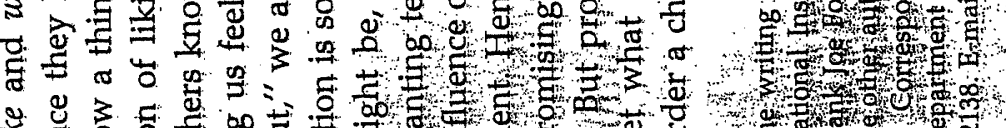

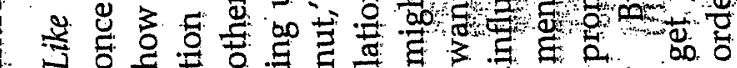

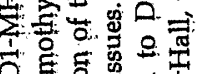

可总

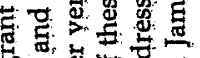

品, 要

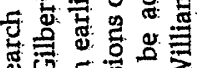

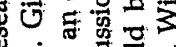

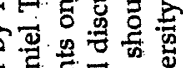

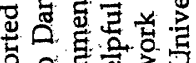

오 굴

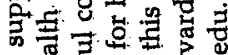

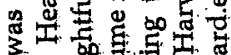

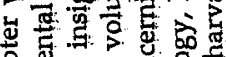

물

o

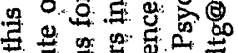

o

op: 240 . Git.

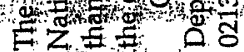


क $\quad$ E

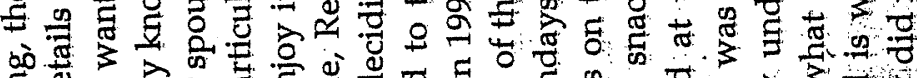

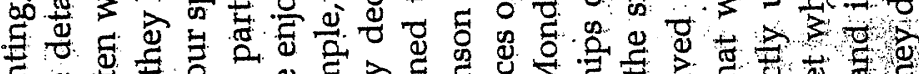

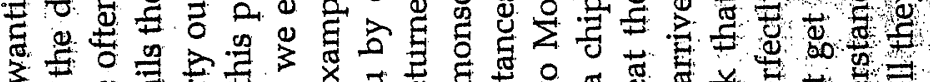

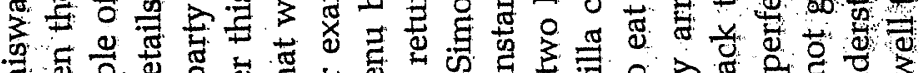

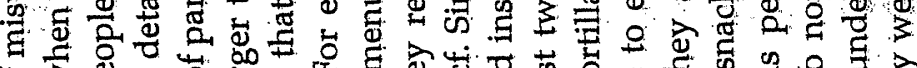

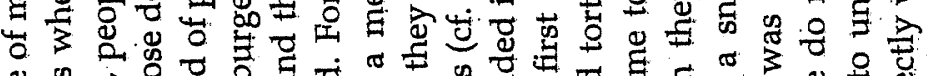

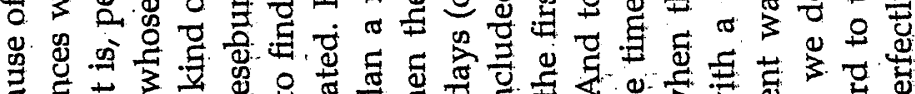
đ 凹 世

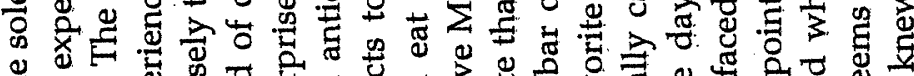
至 0 क

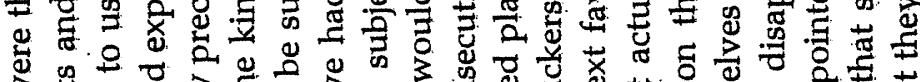

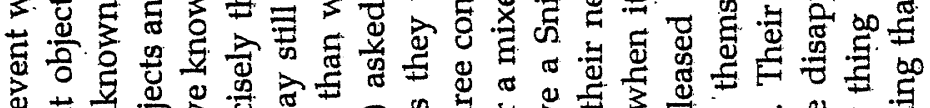

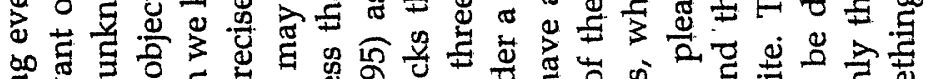

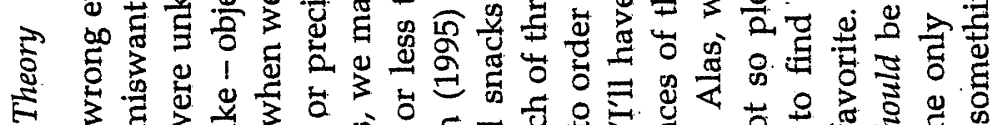

过

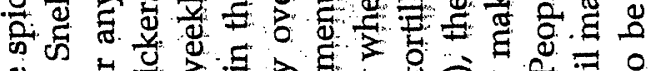

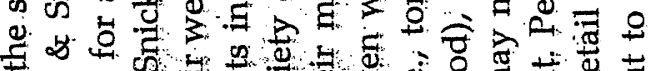
क

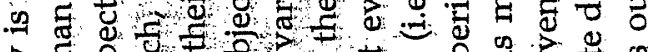

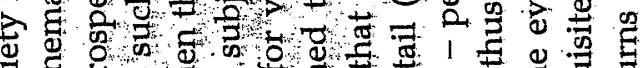

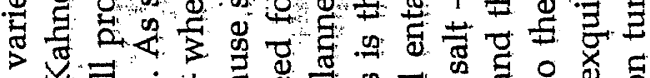

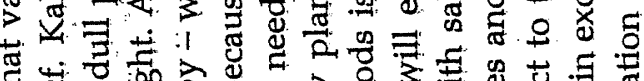
吾 क

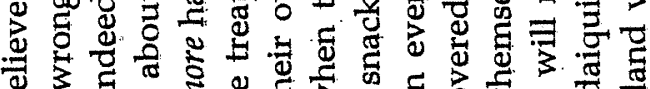
क

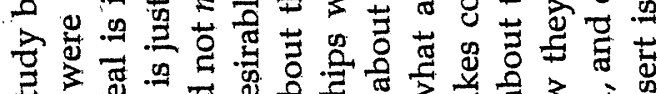
क

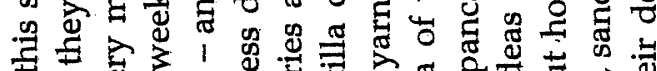
Ð

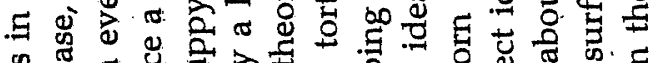

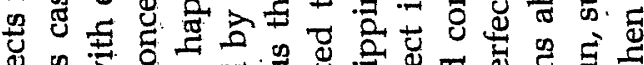
鸟专

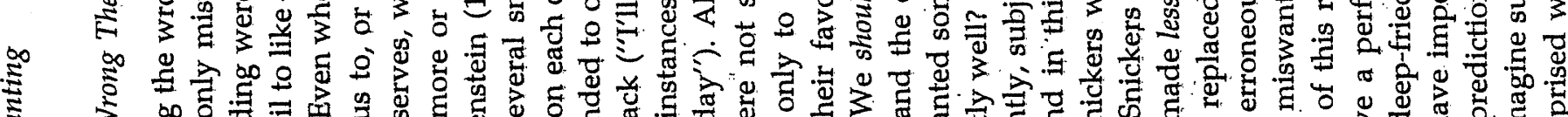

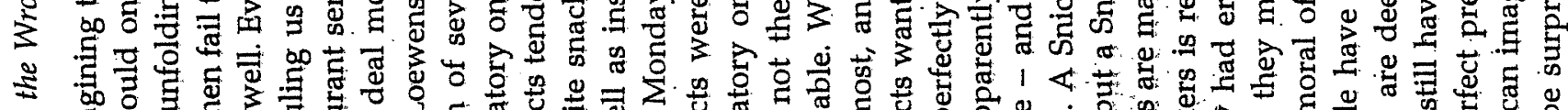

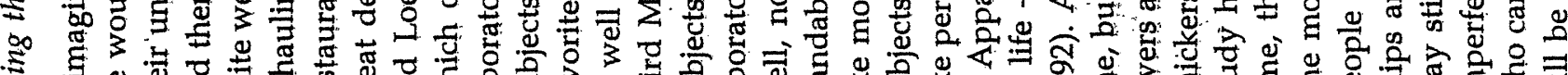

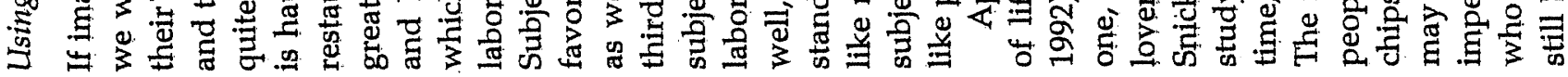

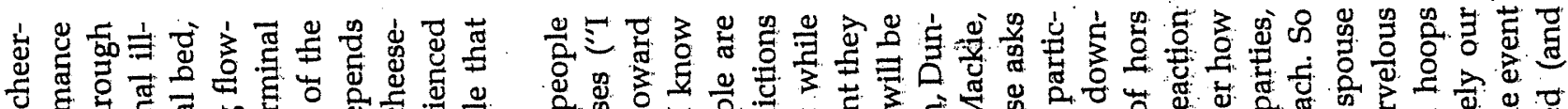

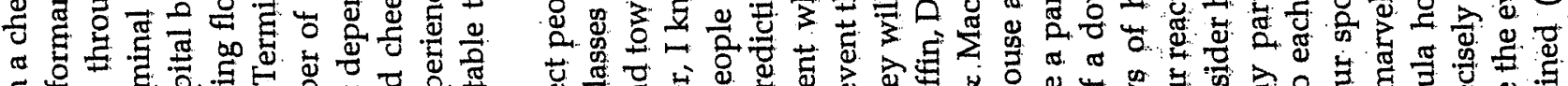

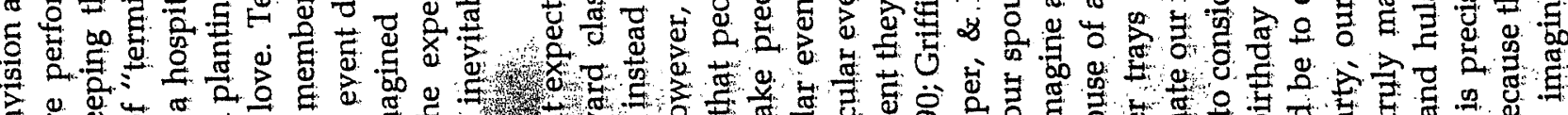

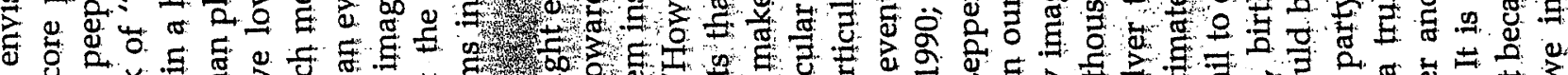
o.

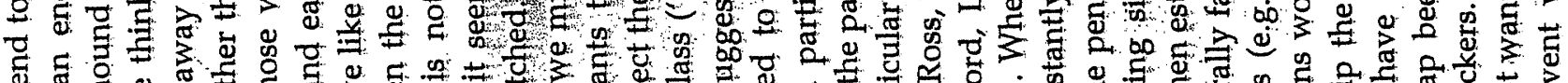
屯 उ फ क 苟

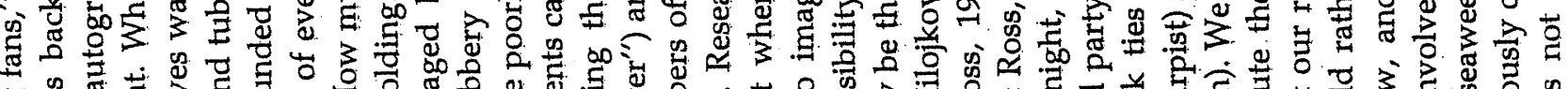
09 क 可

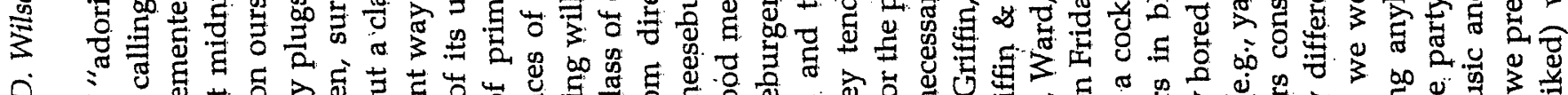
A $\quad$ on

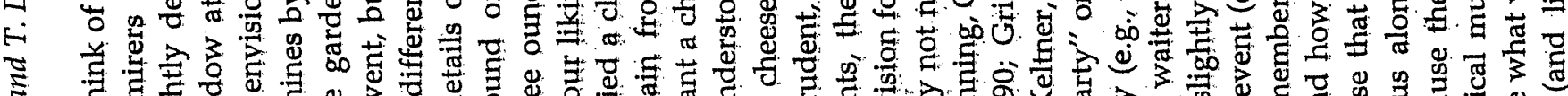

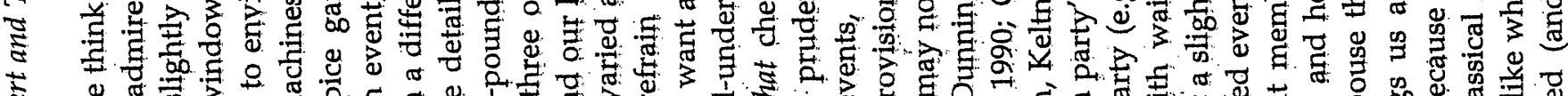
苛 可 उ

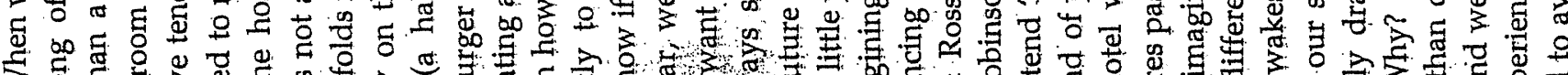

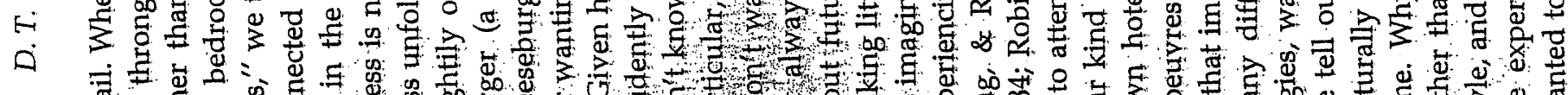

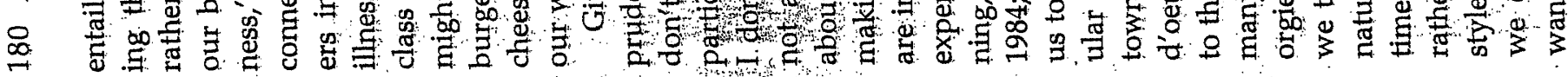




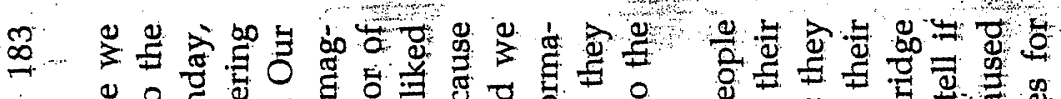

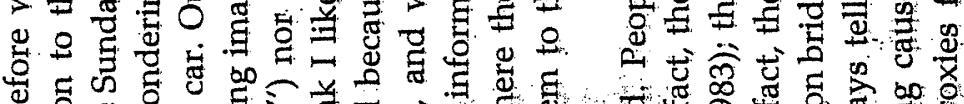

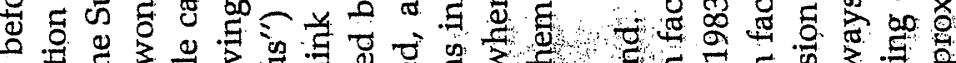

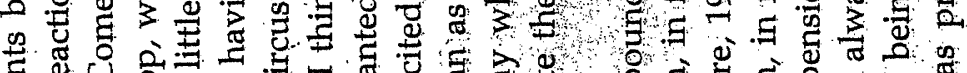
屯U 出

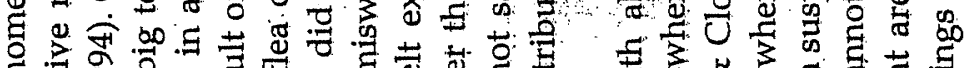

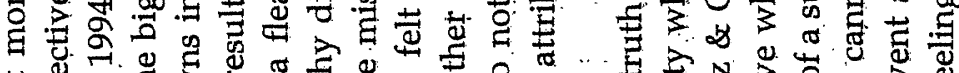

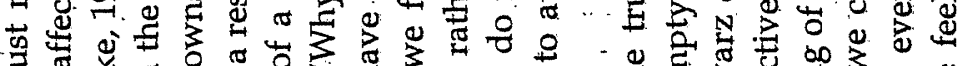

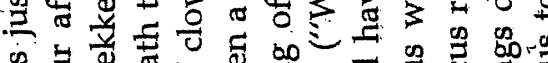

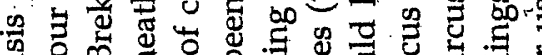

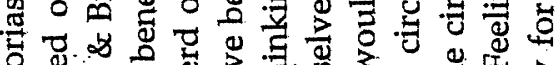

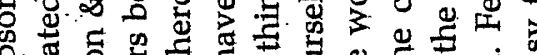

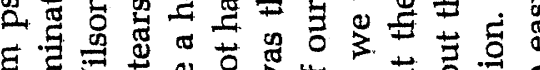

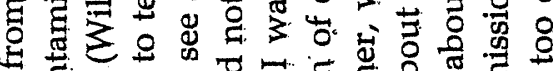

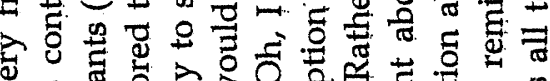

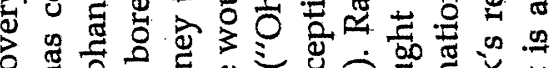
记

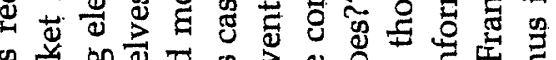

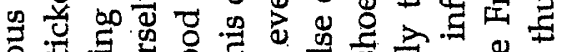

造

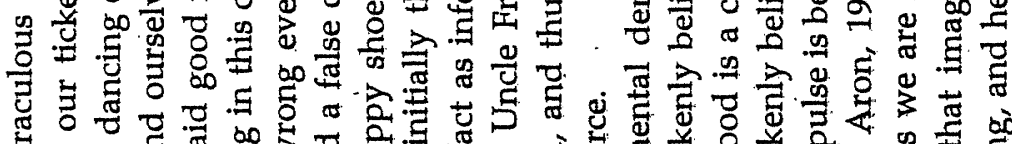
至

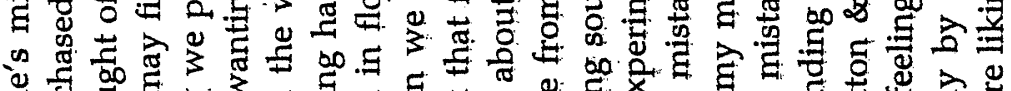

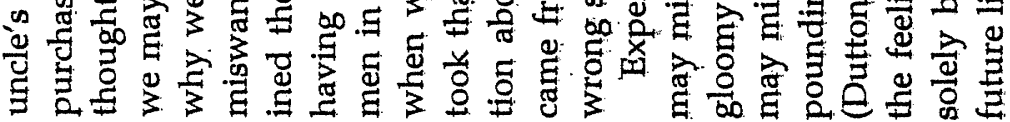

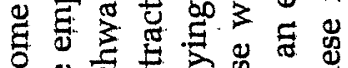

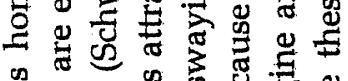

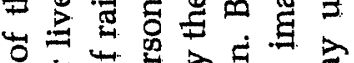

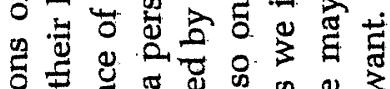

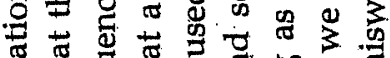

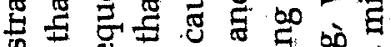
¿

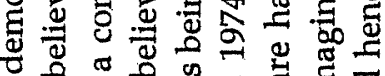

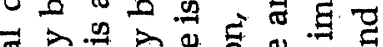

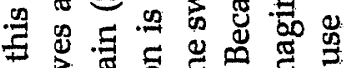

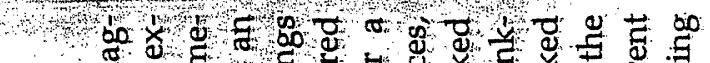
灵 ॠ

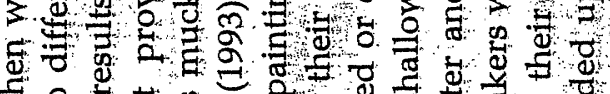

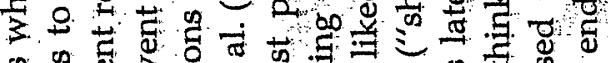
क के

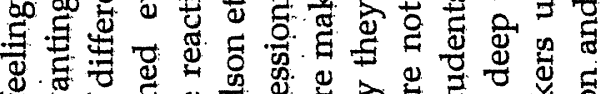
凹. त्व

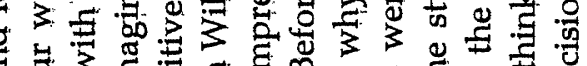

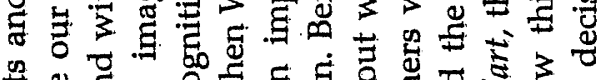

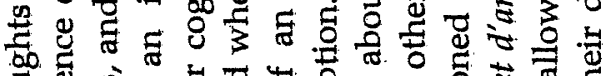

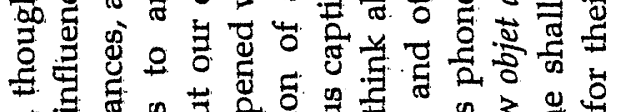

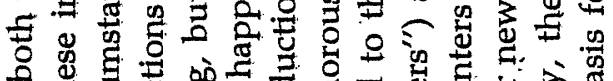

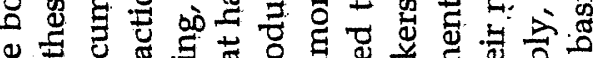
¿ =

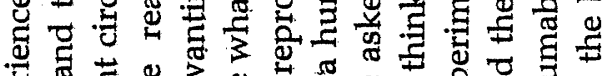

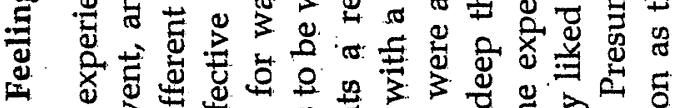

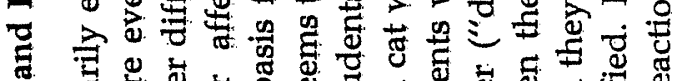

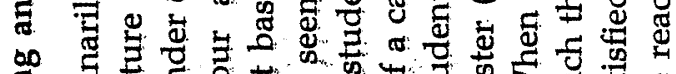

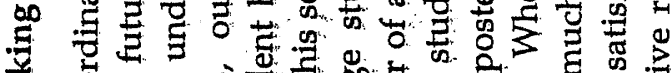

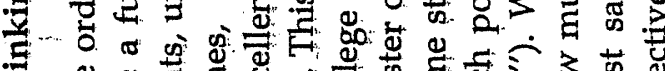

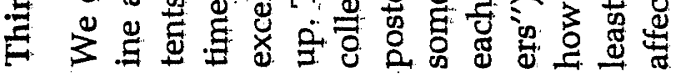

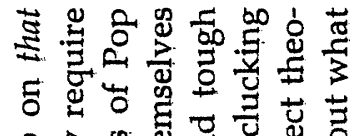

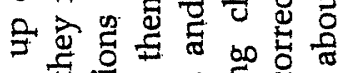
可 을 5

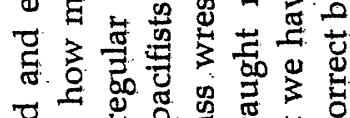
"巳

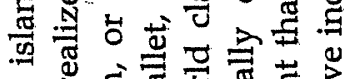
.

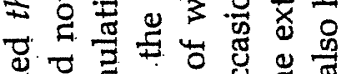

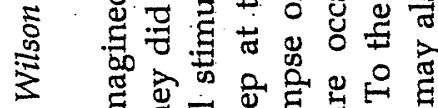

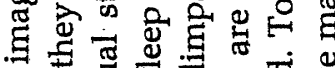

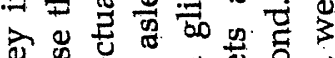
可

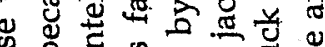
至 苋

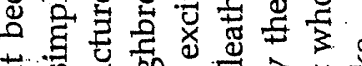
ن. की की Wकx (4) a

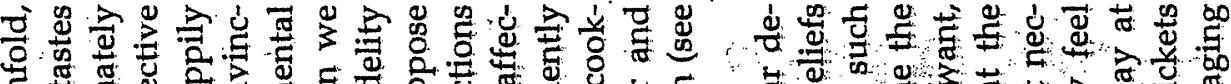

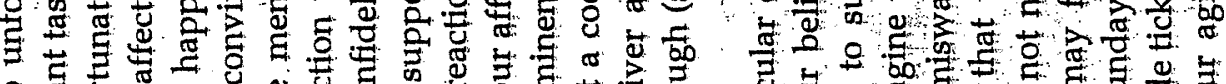
윰

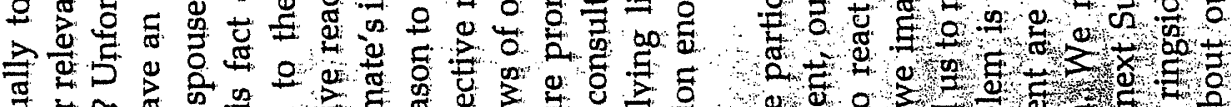
旁 \%

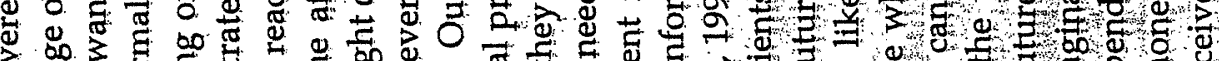

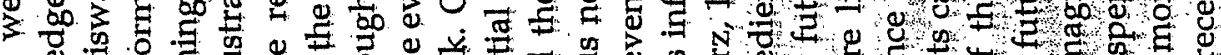

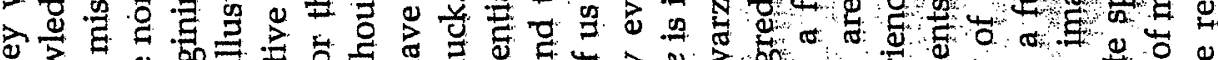

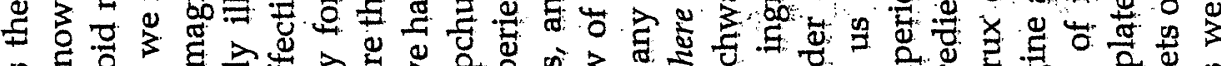

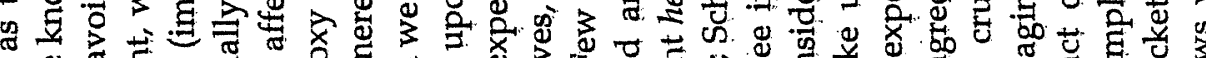
월

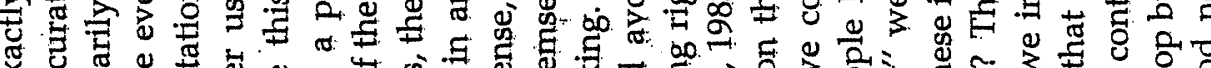
ख

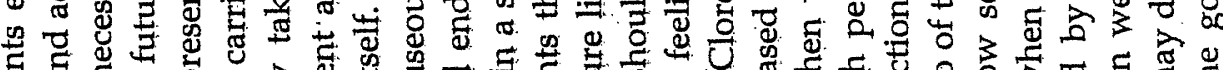

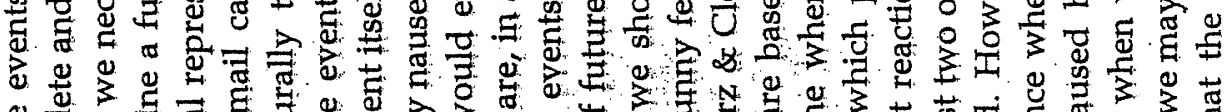

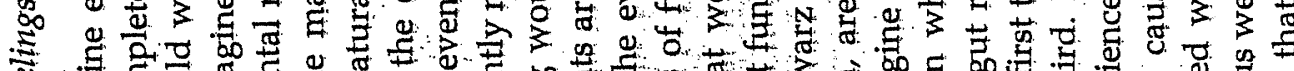

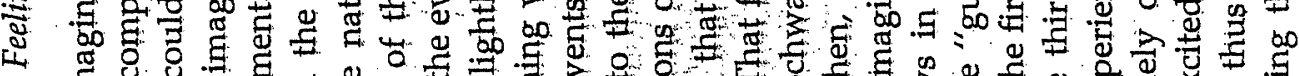
$\infty$ \&

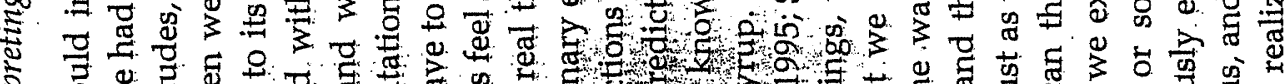

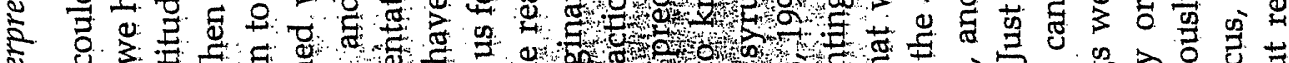

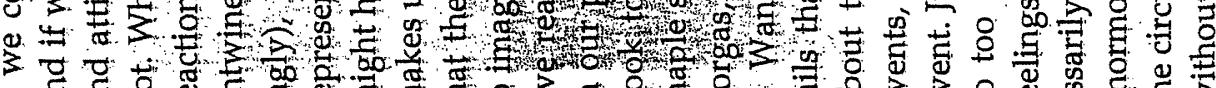

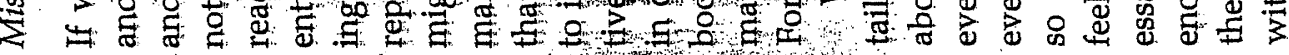




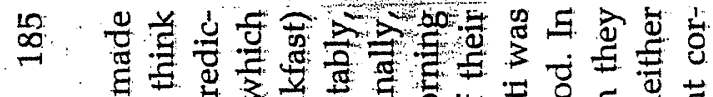

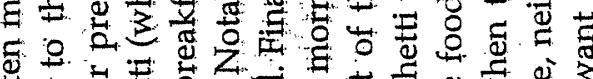

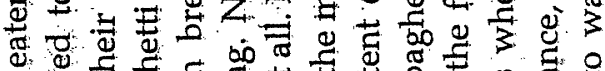
o d o o 等

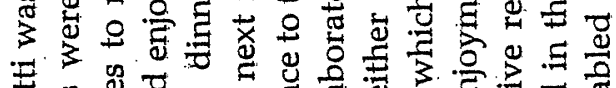

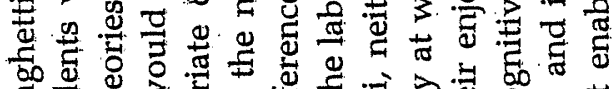

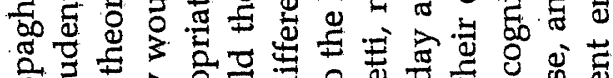
tot

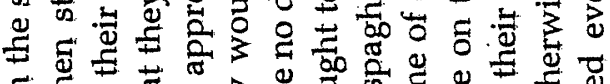

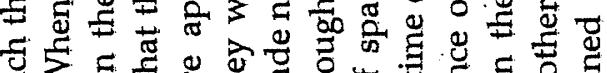

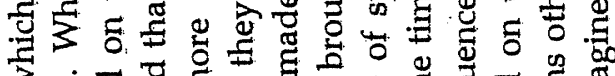

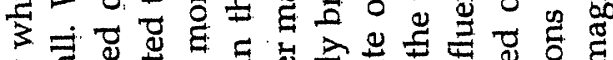
के

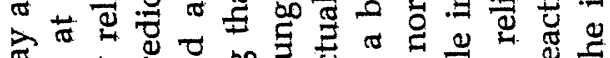

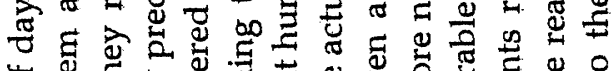
故娄

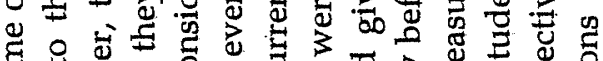

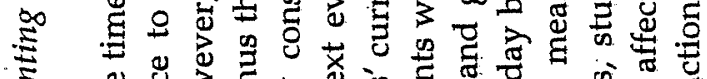

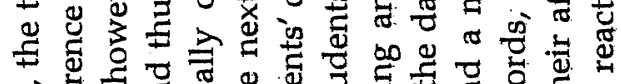

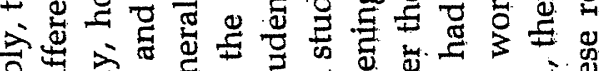

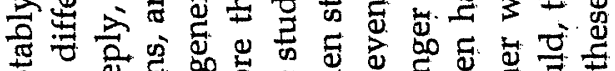

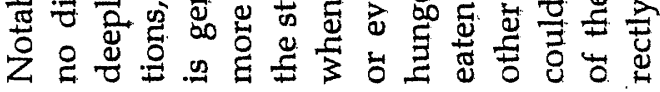

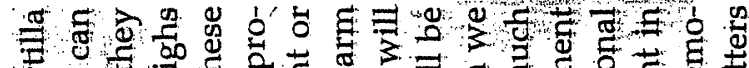

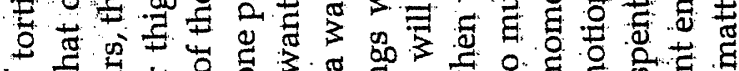
D.

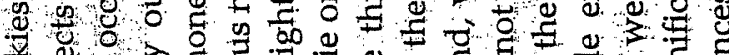
क o

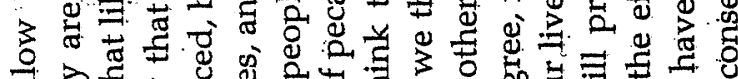
월 E E \&

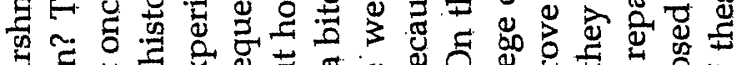
령 घ क⿺辶寸 兽.

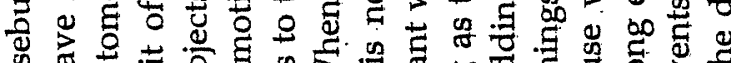

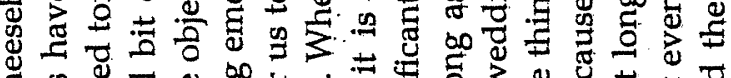

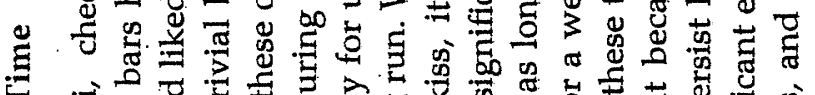
-

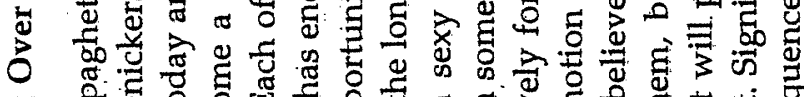

o क की

ำ

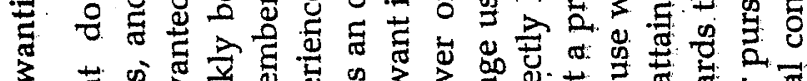

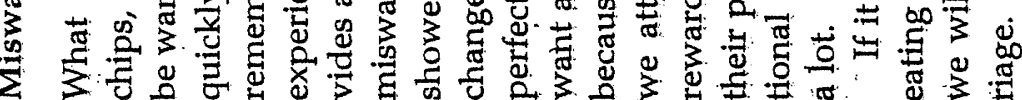
क

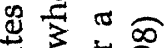

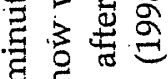
द्व

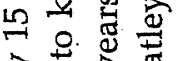
ลิ

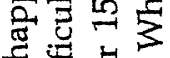

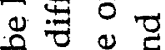
$30 \stackrel{0}{0}$ के () ह छ 3 의

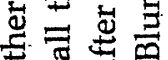
(d) ब $3 \pm$ 岳

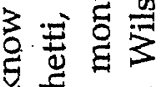

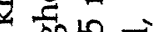
० \# के हि

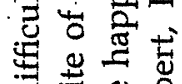
흐 을 少

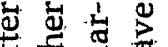
-

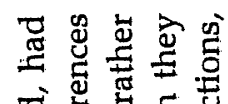

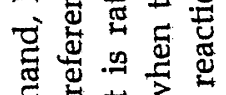
政 t.

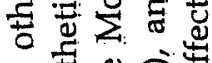

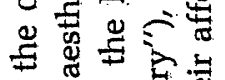
5 5.9 政 sis. 㖓。

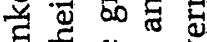
द

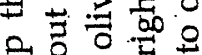

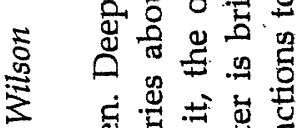

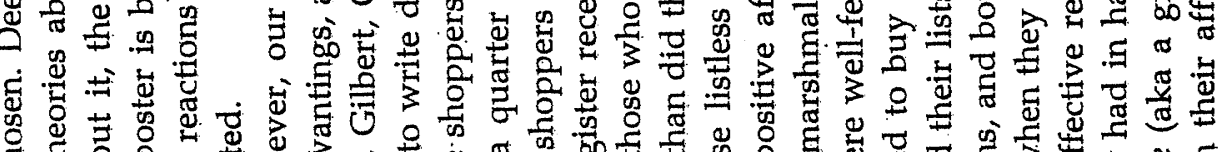




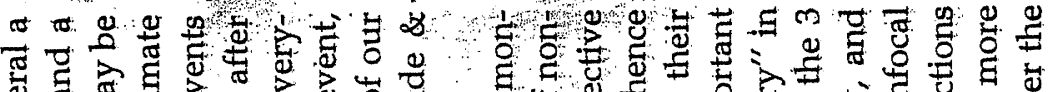

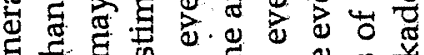

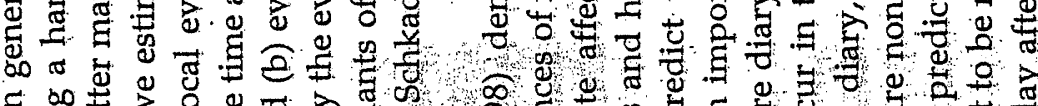

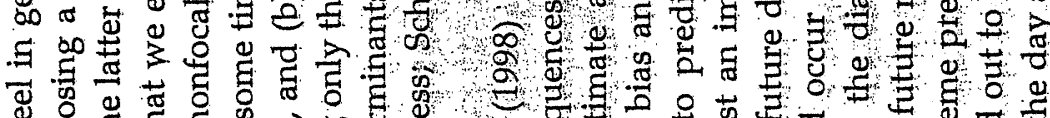

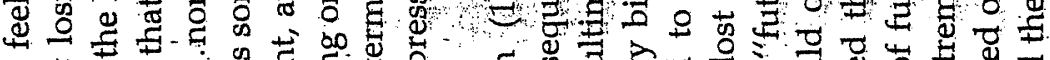

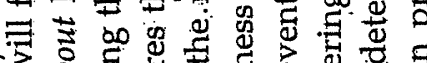
उ.

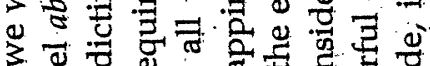

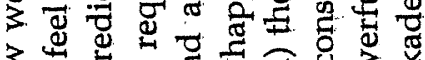

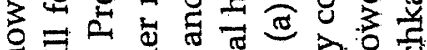
工

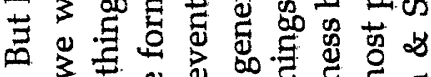

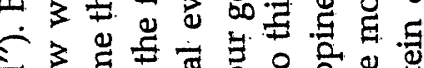

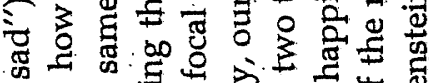

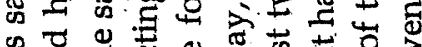

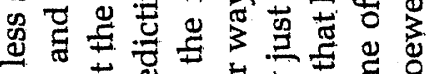

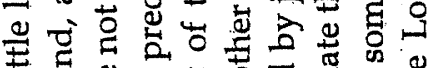

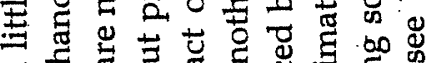

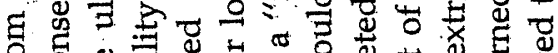
की

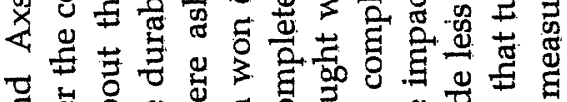

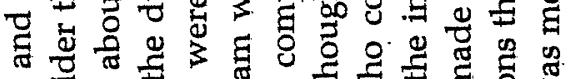

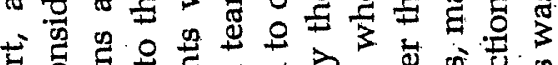

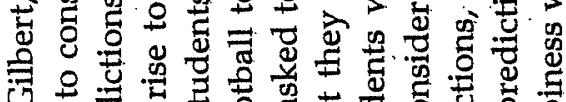

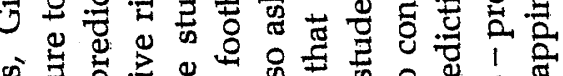
के

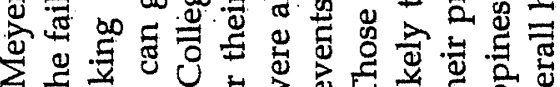

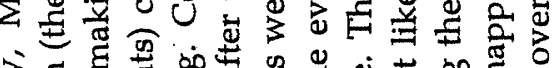

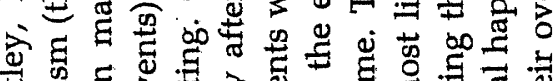
๘

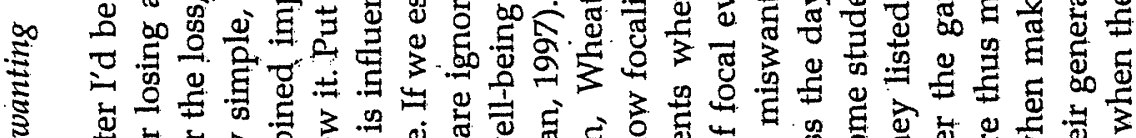

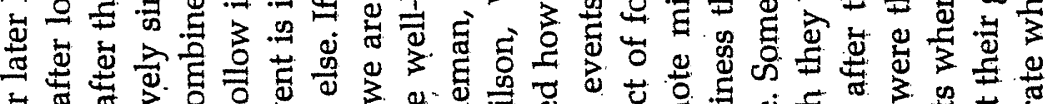

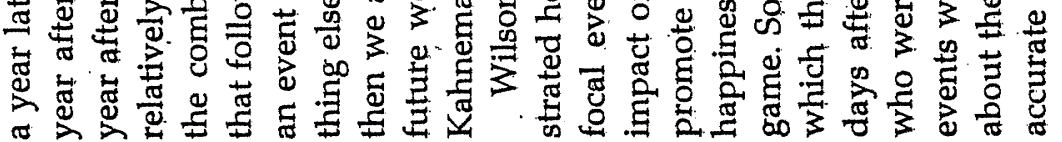

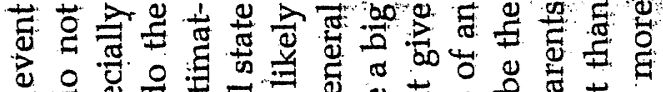

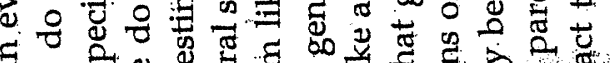
ते 艺

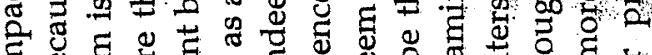

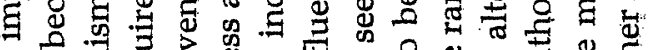

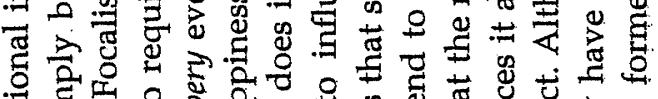
豆

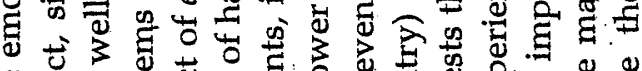
凹 م.

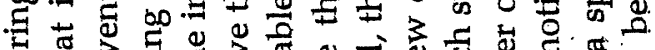

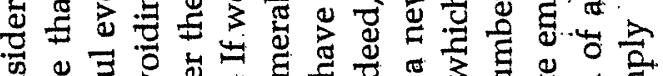
Ð \&

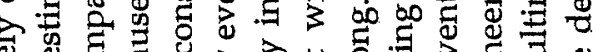

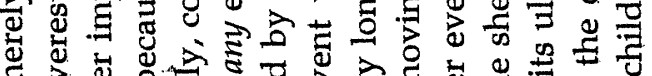

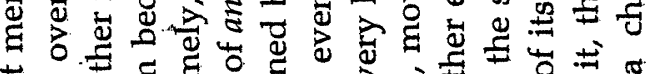

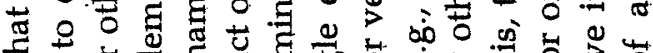

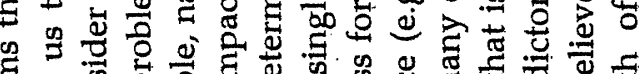
है 它 岕

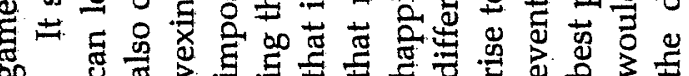

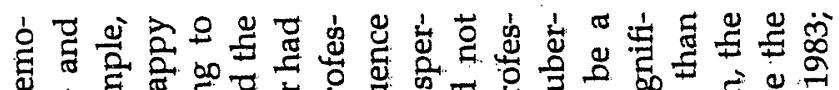

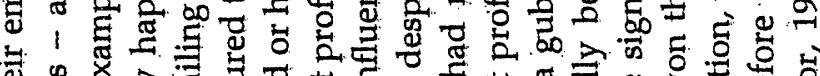
至 士

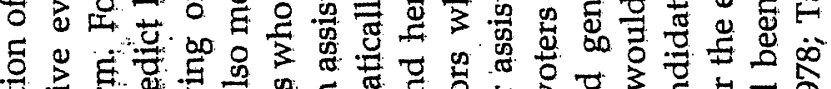

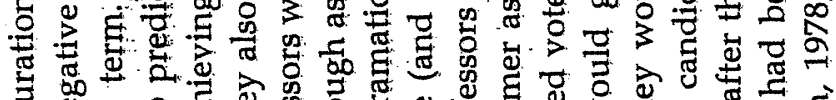
일

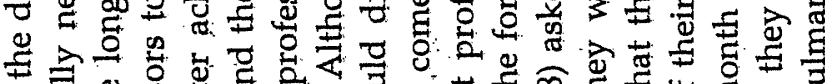

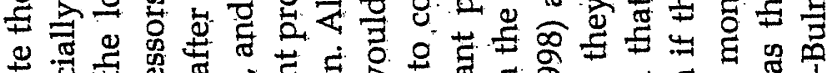

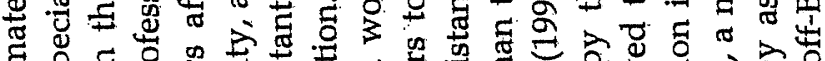

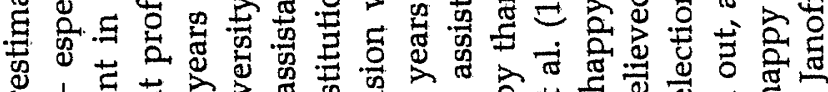

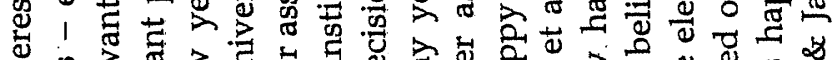

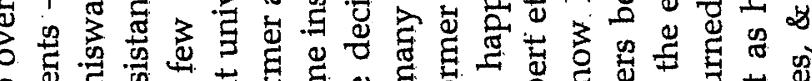

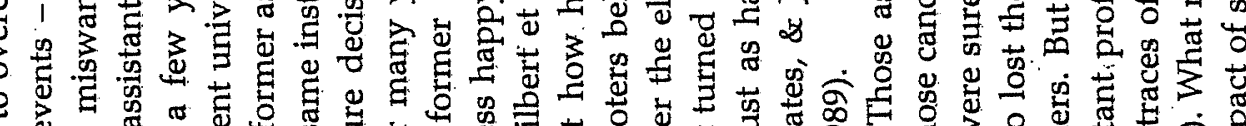
(4

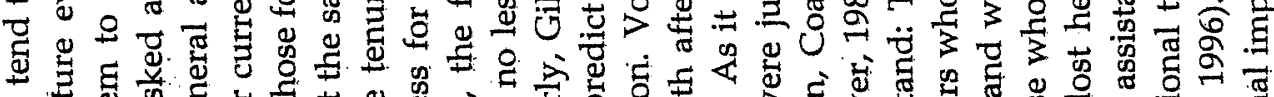

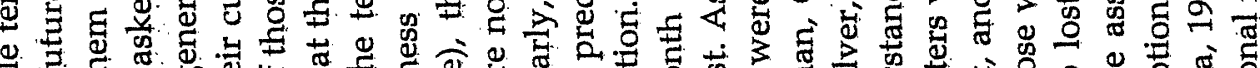

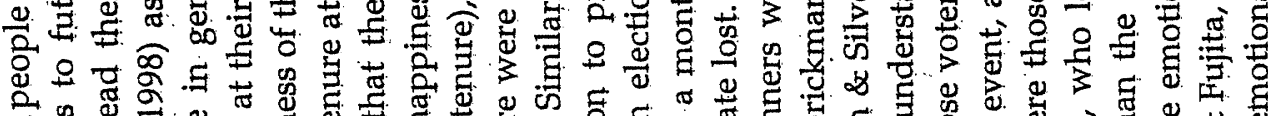

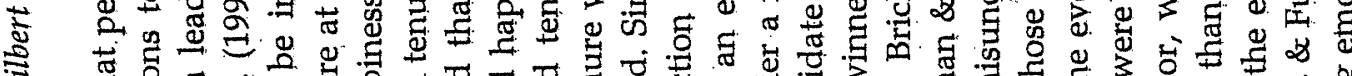

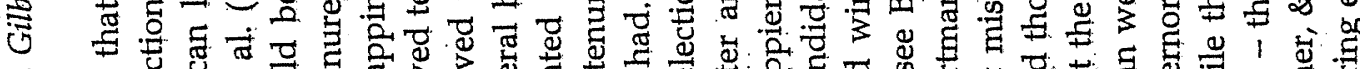

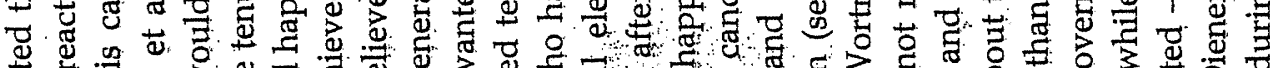

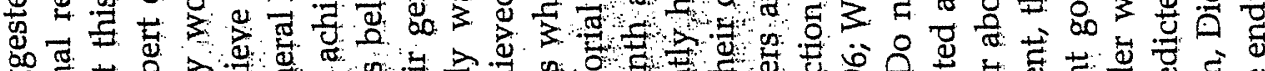

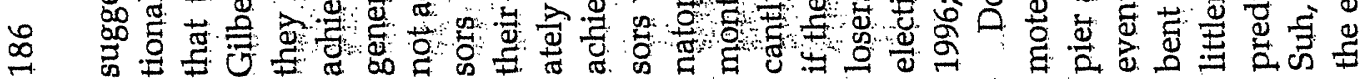

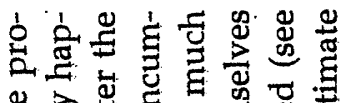

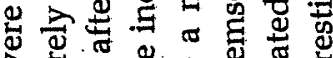
认为 1 至

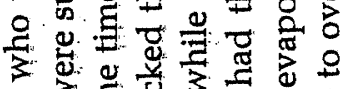

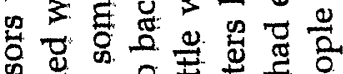

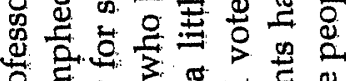

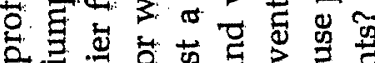
+

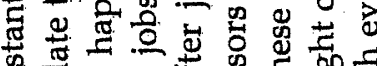

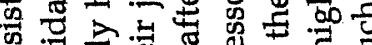

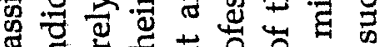




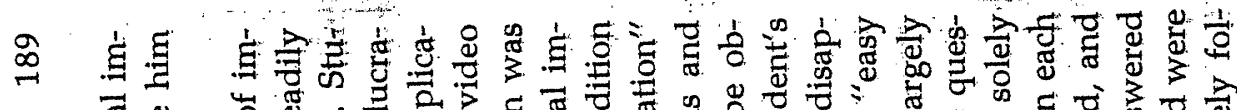

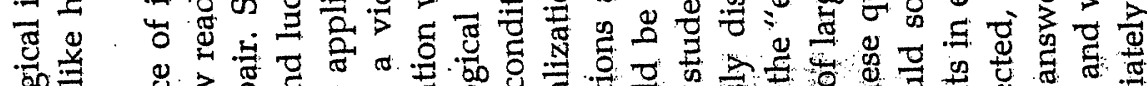

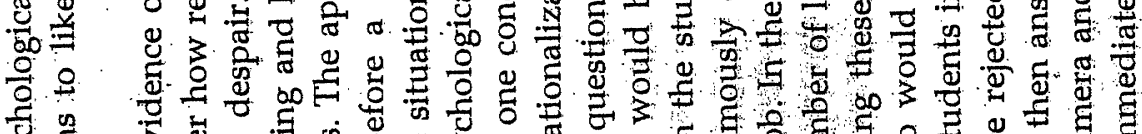

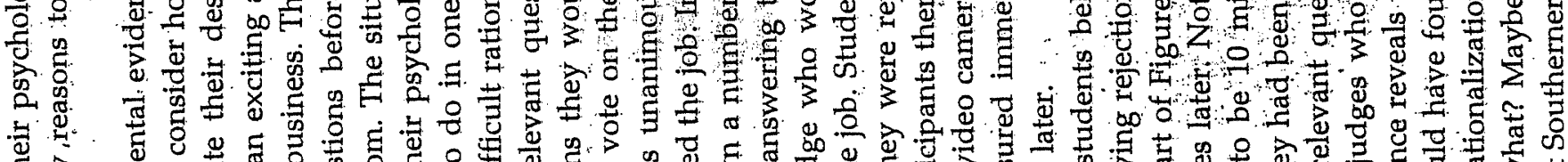
过

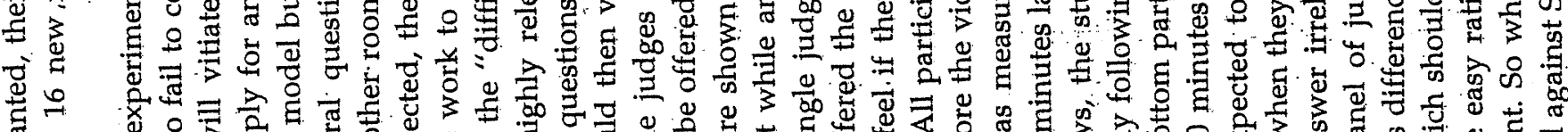

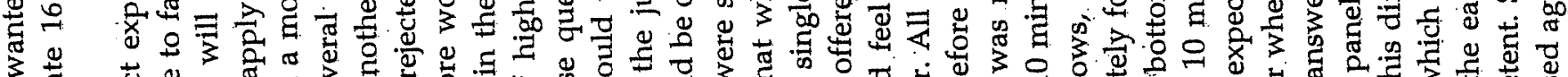

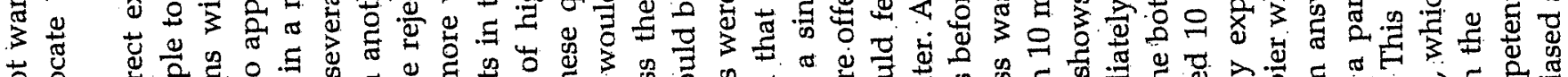

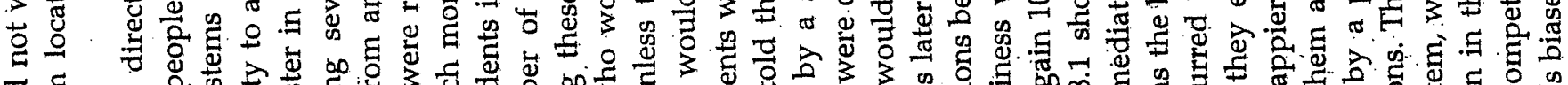

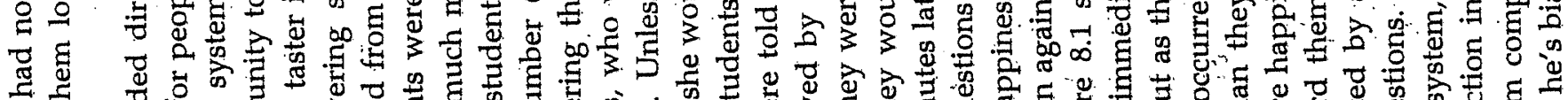

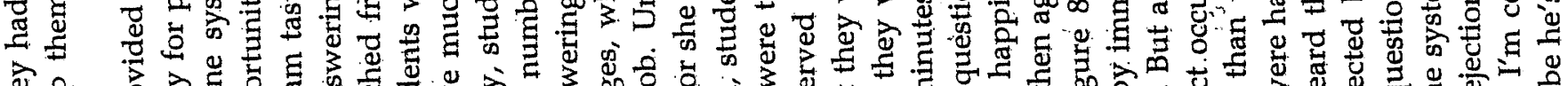

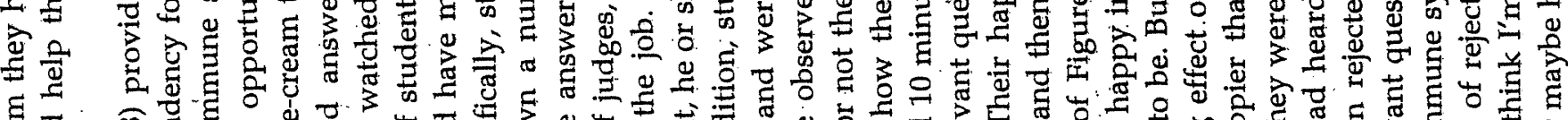
छ

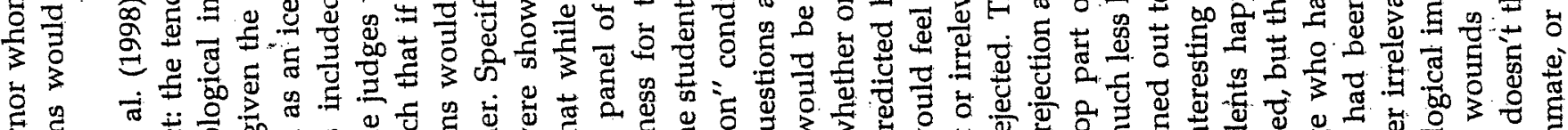
द्वे ए क क क

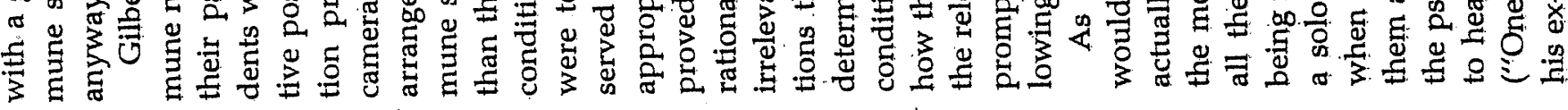

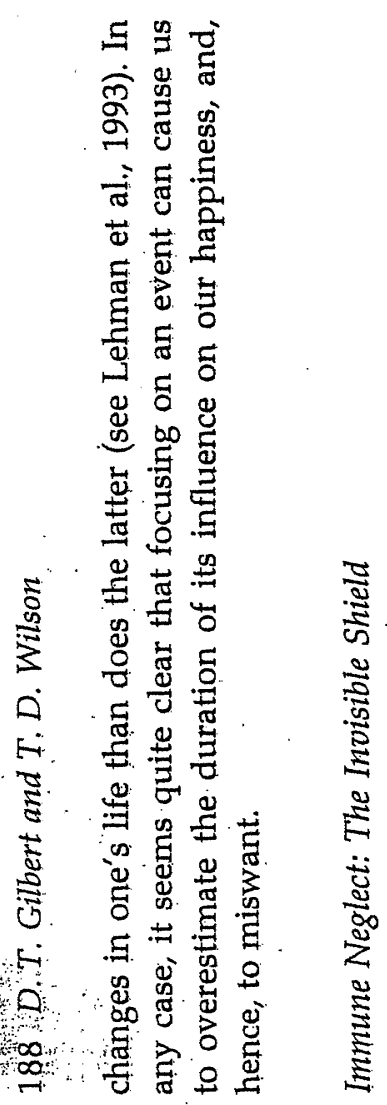

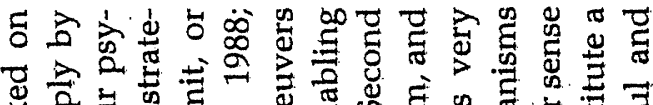

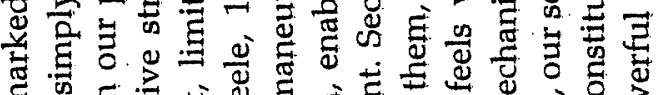

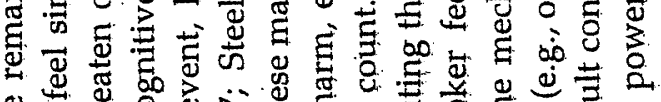

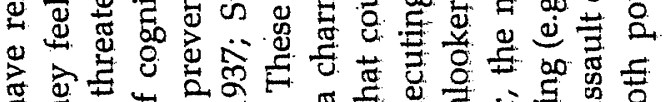

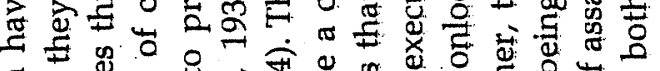

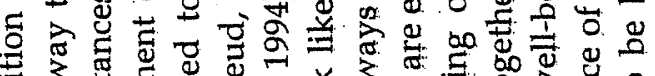

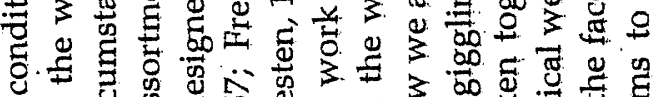

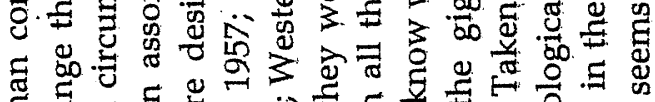

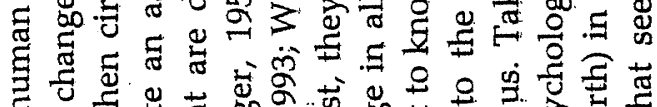

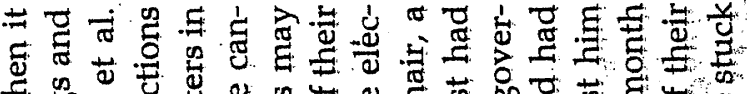
E.

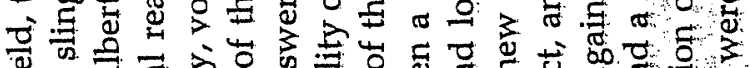

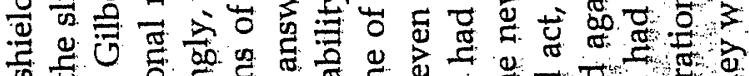

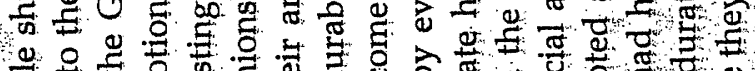

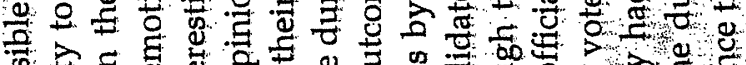

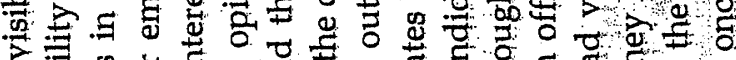

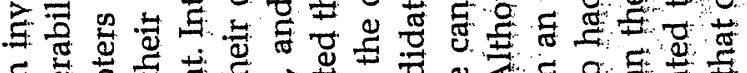

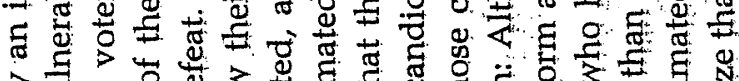

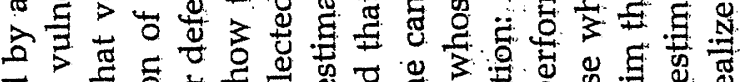
उ

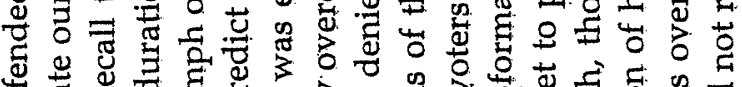

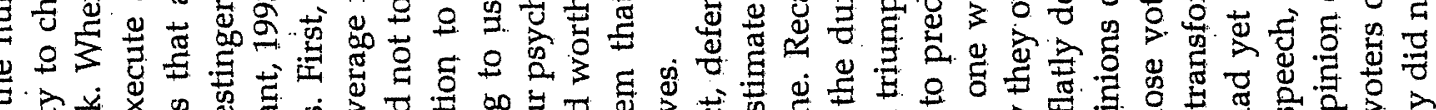

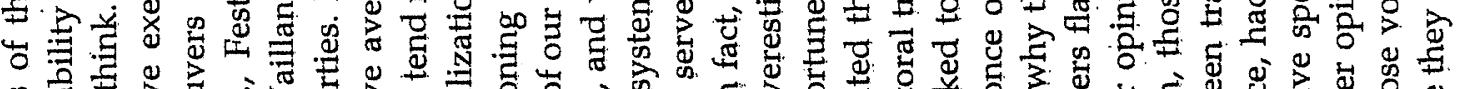
क

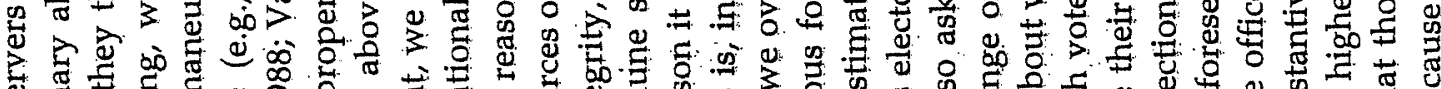

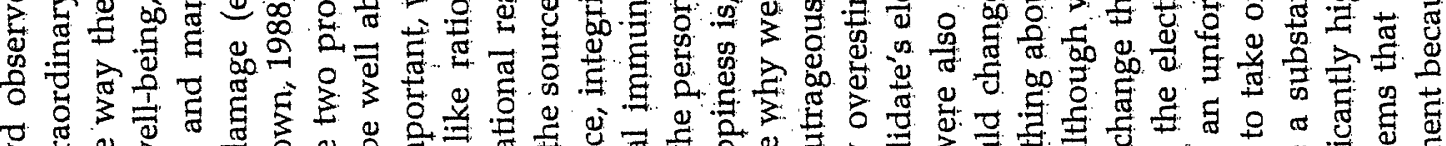
월

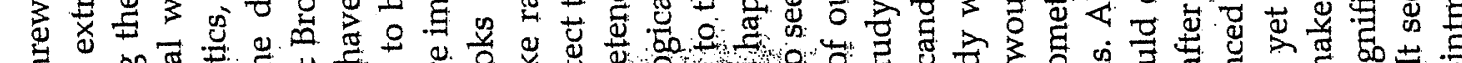

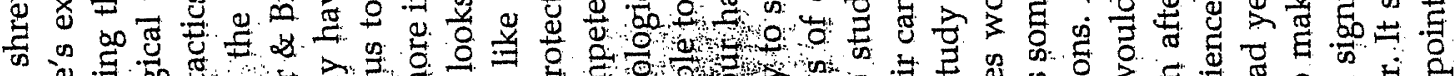

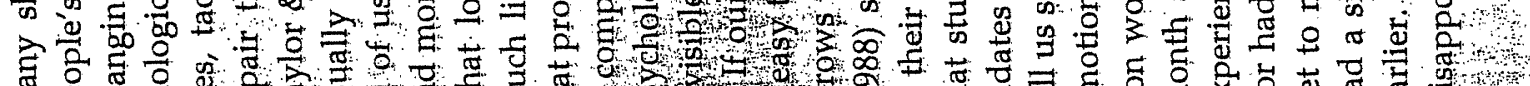

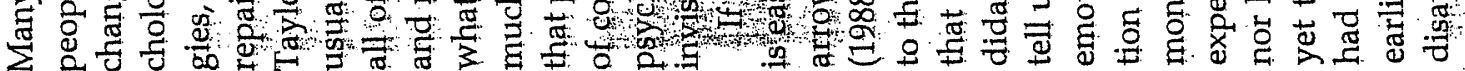




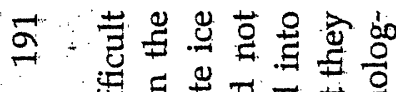
语

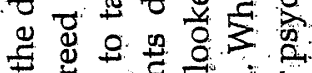
दs

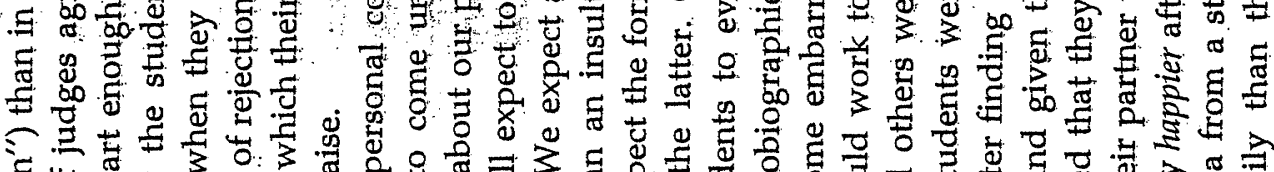

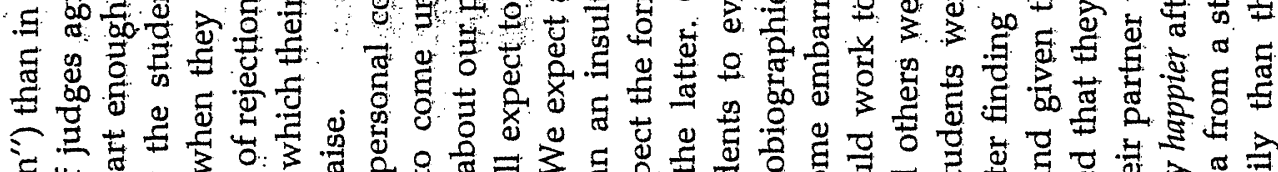

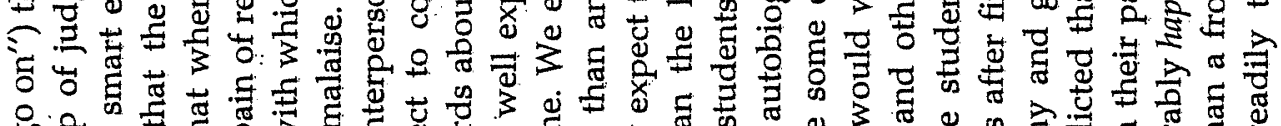

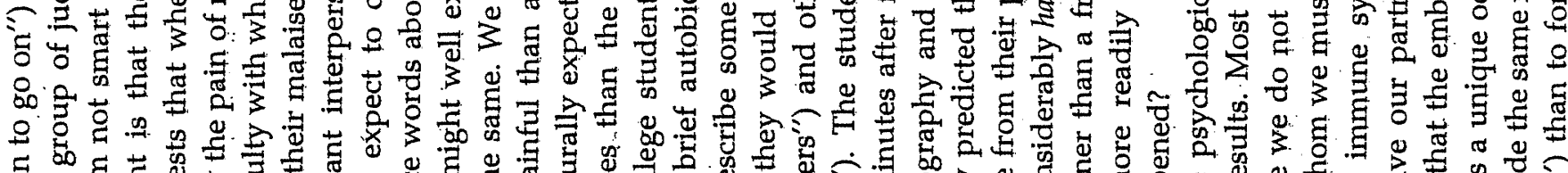
E

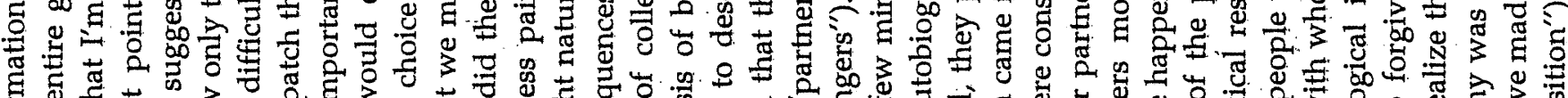

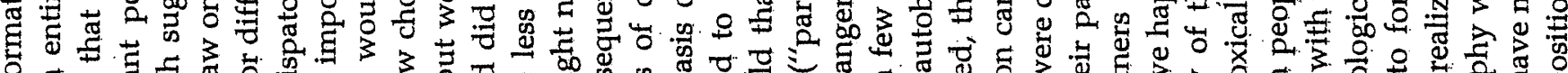

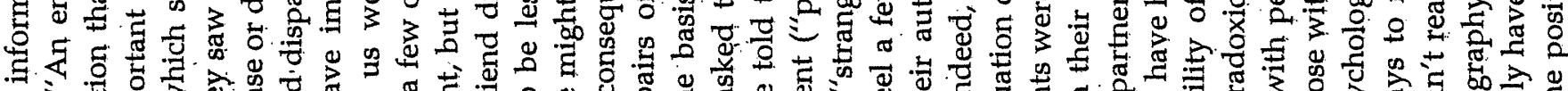

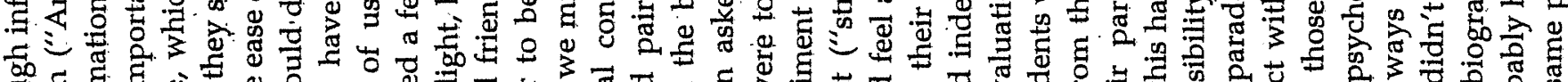

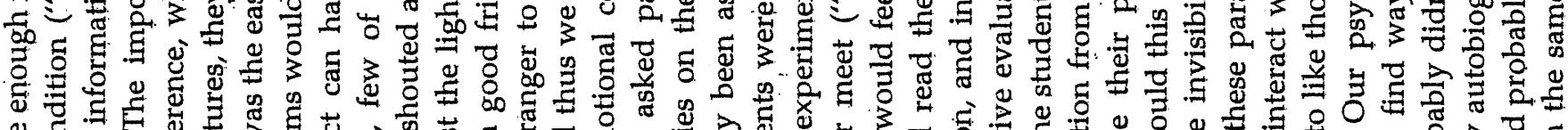

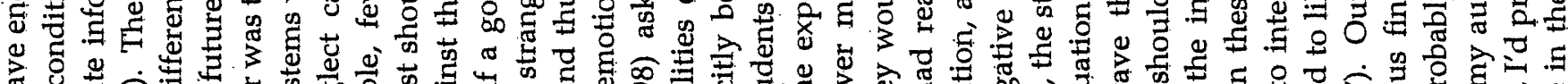
o

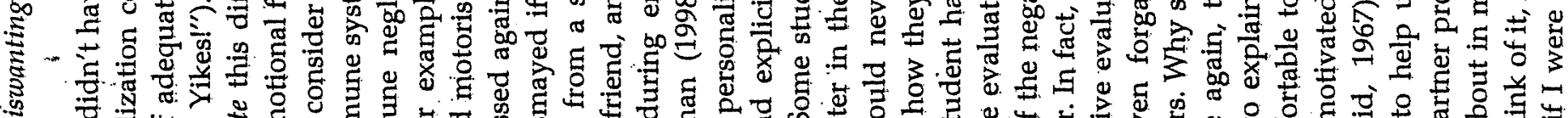

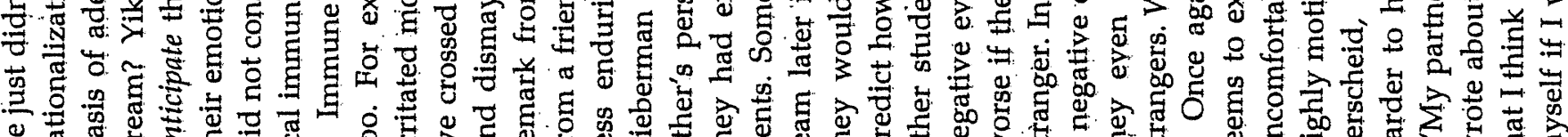

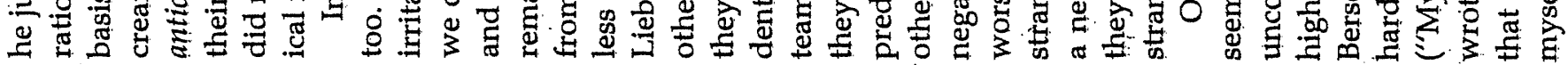
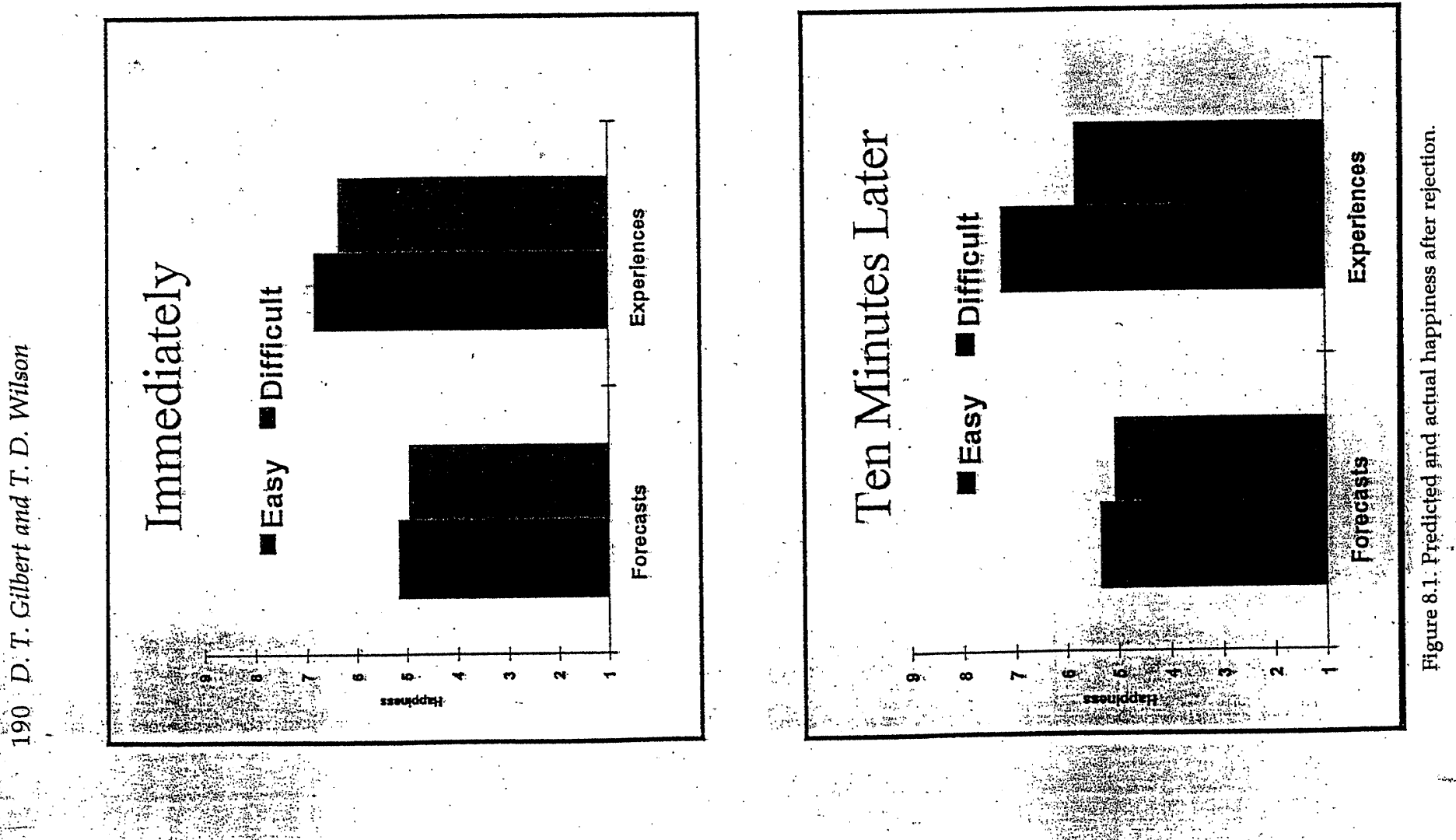


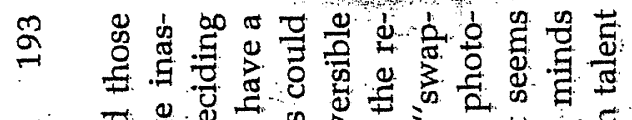

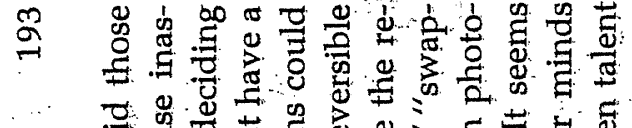

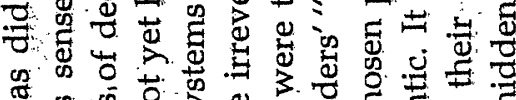

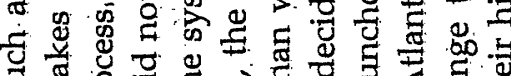

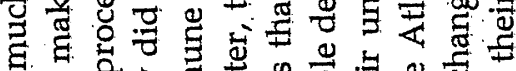

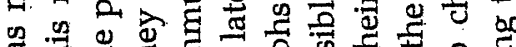

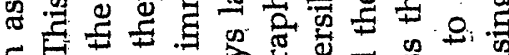

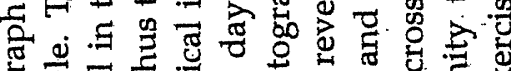

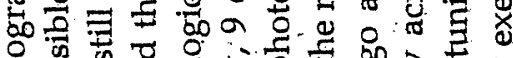

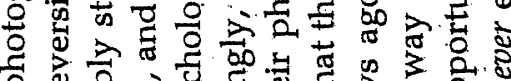

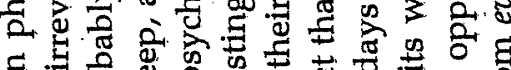
ङ

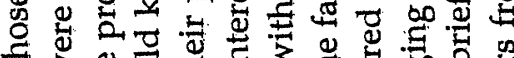

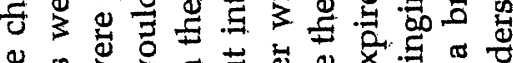

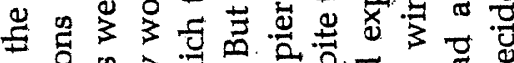

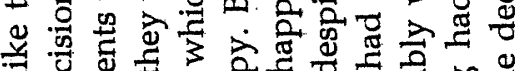

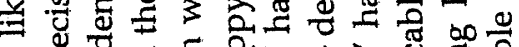

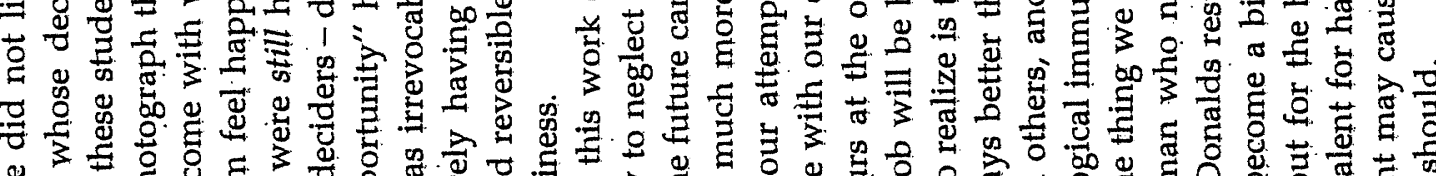

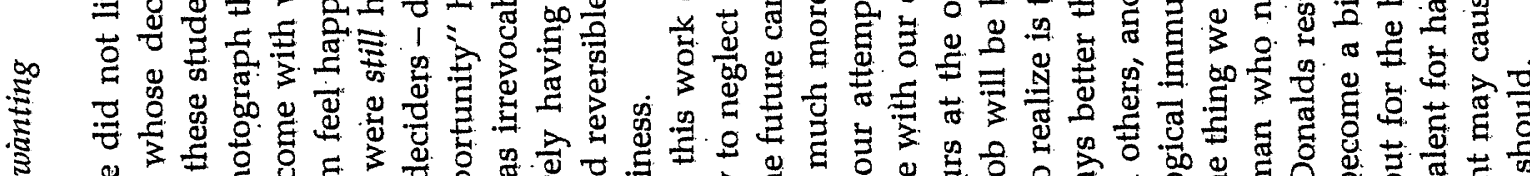

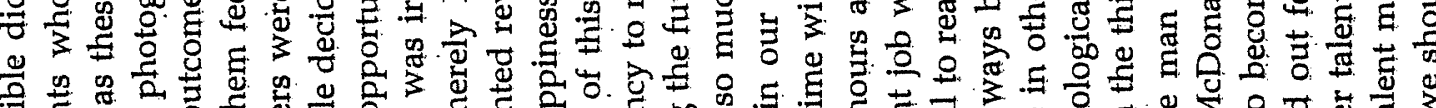

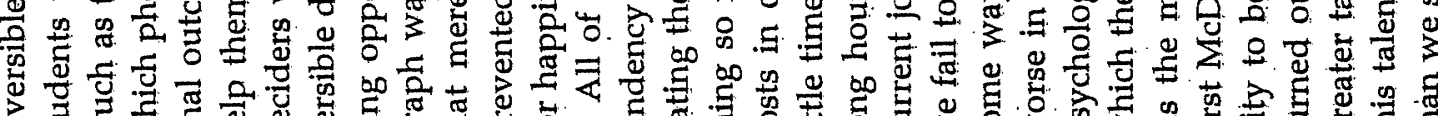

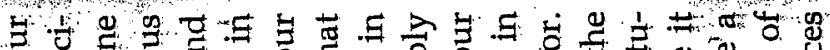
0 유.

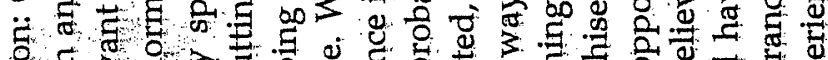
- द

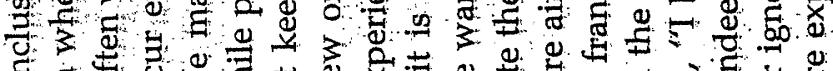

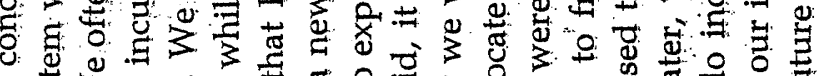

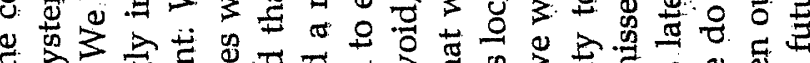

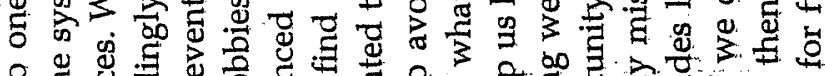

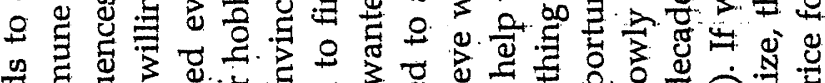

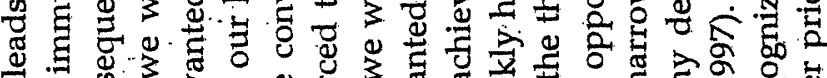
—.

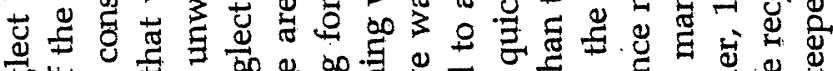

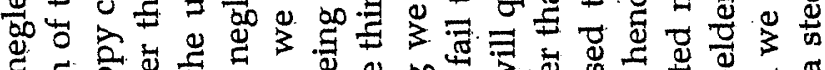
¿

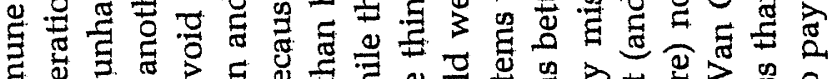

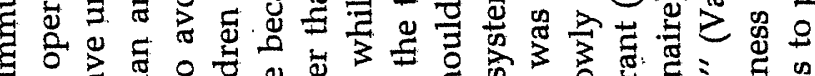

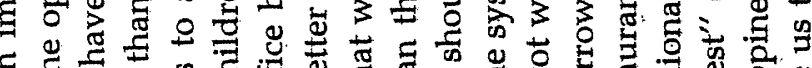

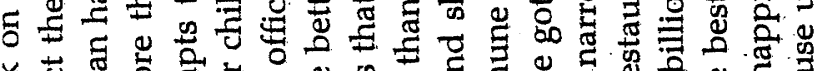

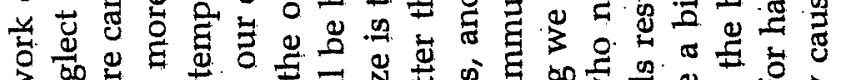

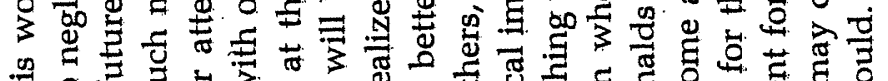

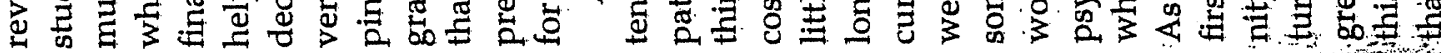

$\sum \stackrel{\leftrightarrow}{2} \stackrel{1}{2}$ 的卉

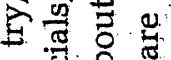
$\stackrel{0.0}{2}$ 3 䨔

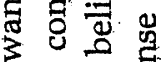
i 5 吉 了娄。

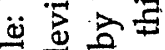
政 淟岁焉 으 ह o 焉

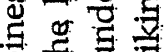

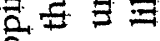

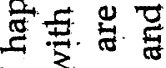
$4>$ 出 0

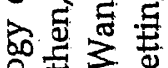
舟

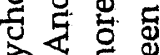
क 0 है

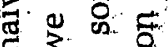
E. 12 这

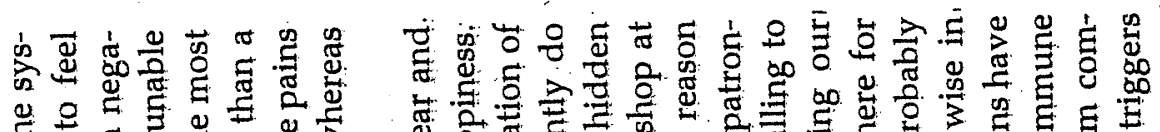
E

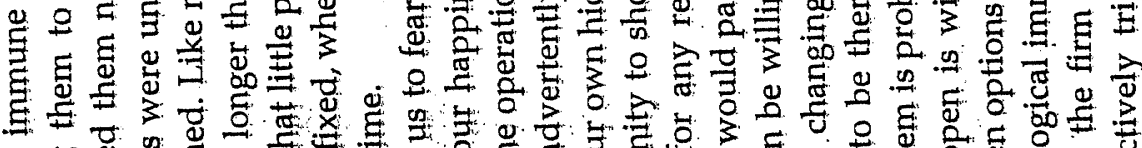

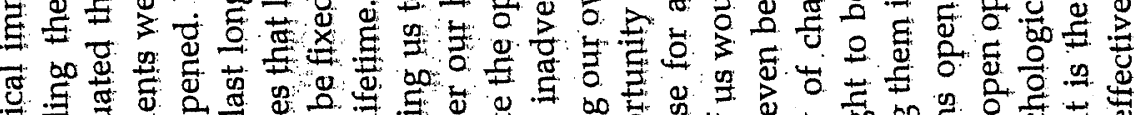

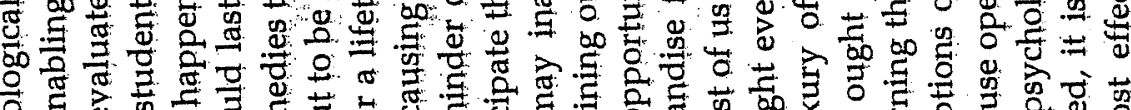

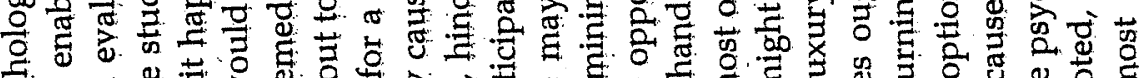

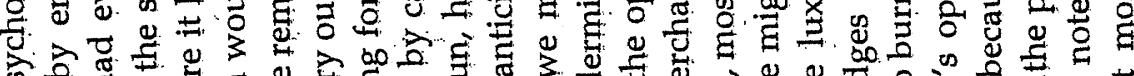

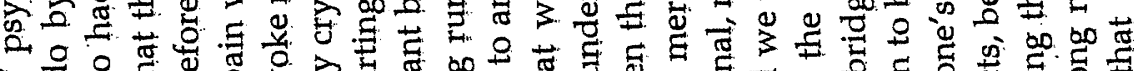

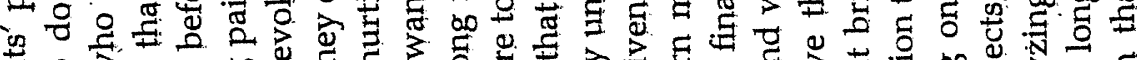

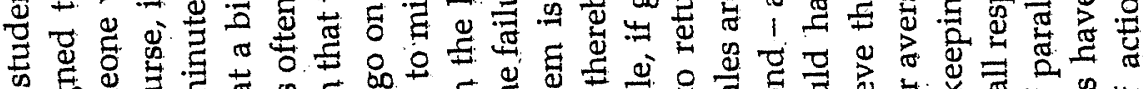

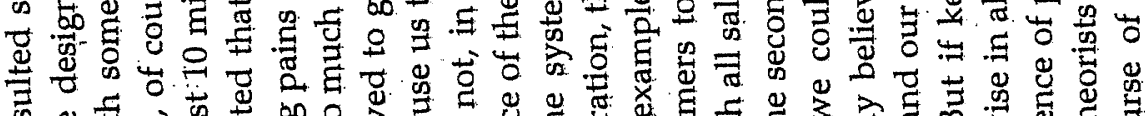
ज.

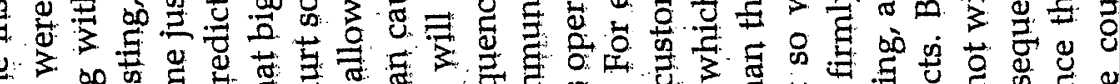

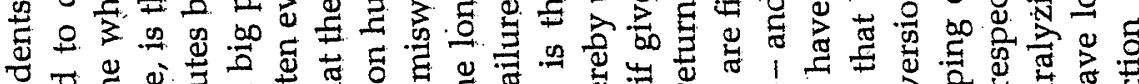

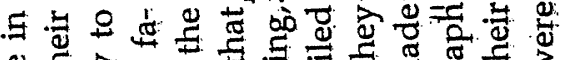

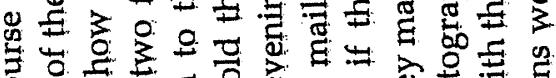

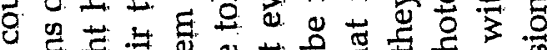

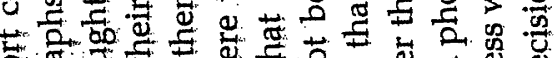

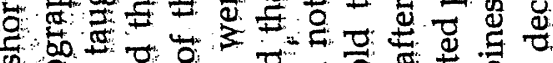

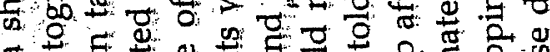

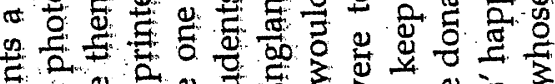

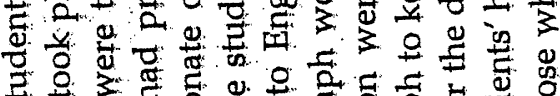

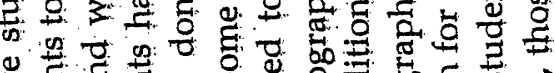

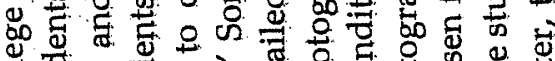

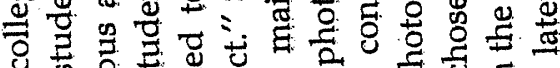

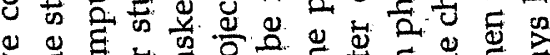

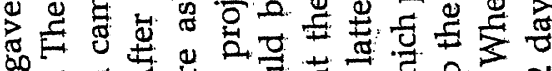

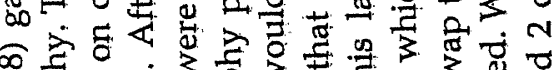
مै

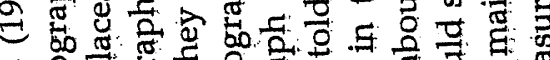
क 0 ए

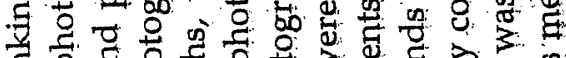

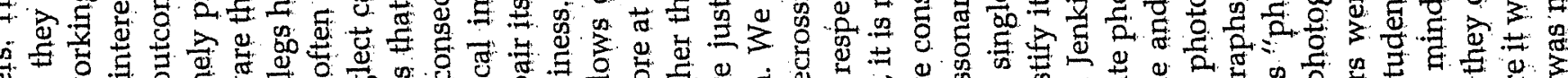

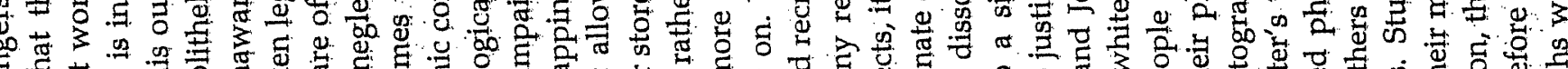

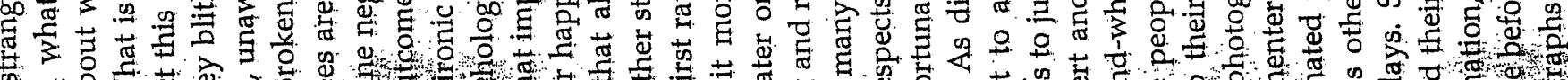

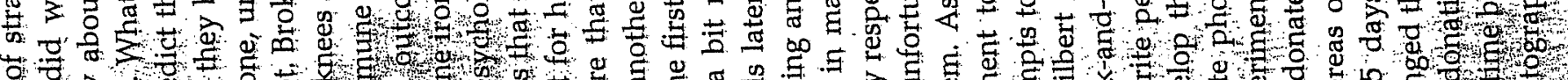

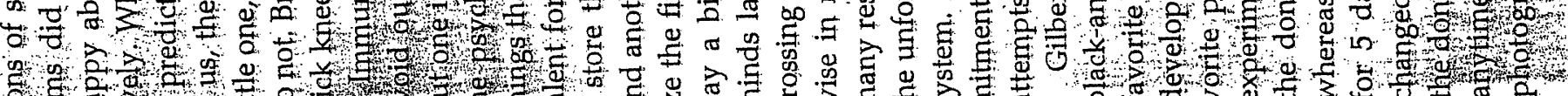

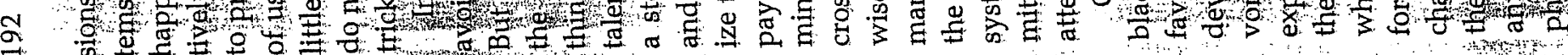


$\stackrel{2}{2}$

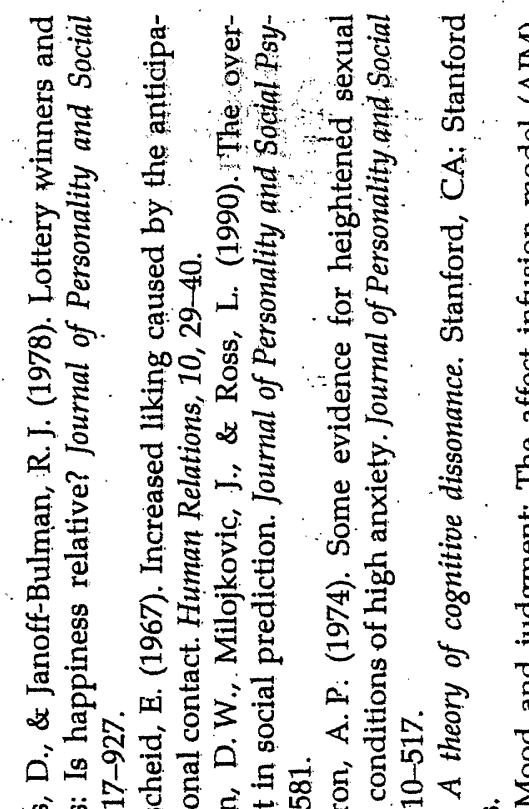

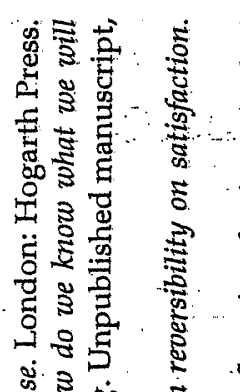

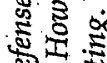

केष

要

空

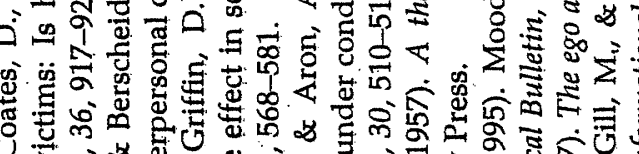

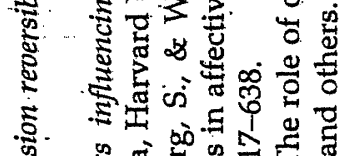

政

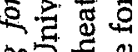

恶

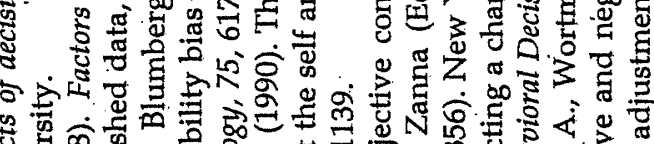

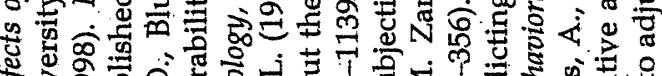

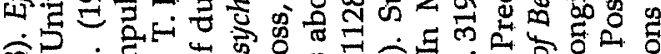

ब.

E.

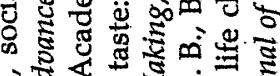

बं से द्ये

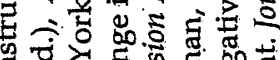

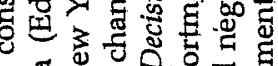
o 舟
密

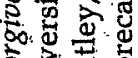

क.

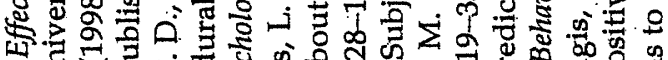

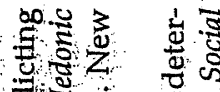

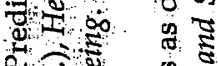

s.

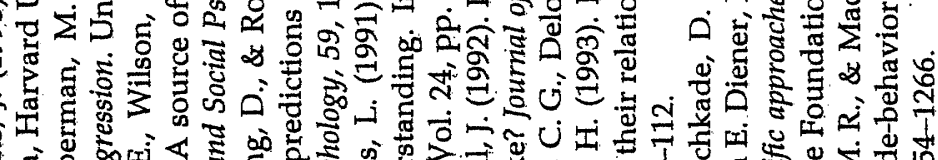

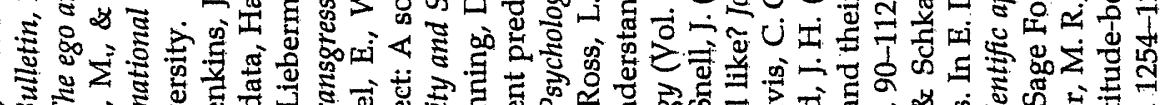
然

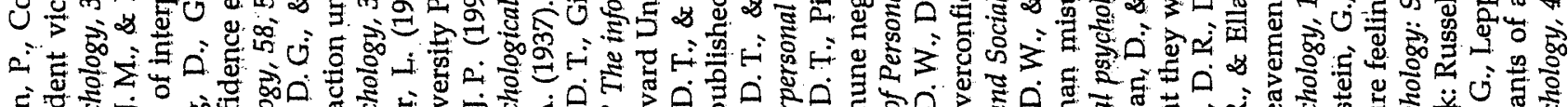

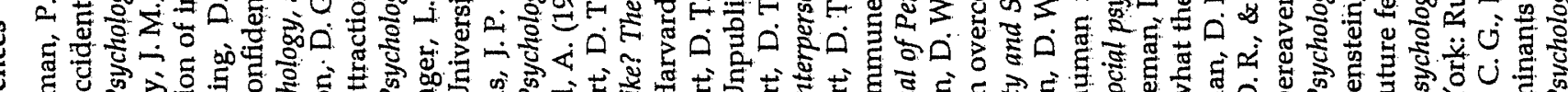

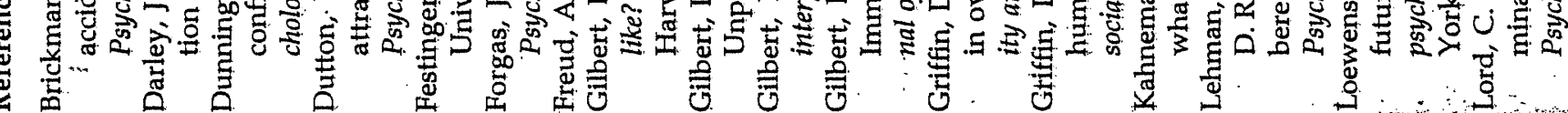




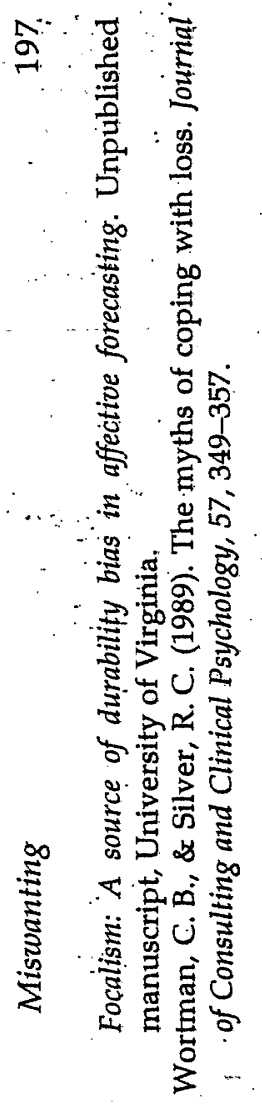

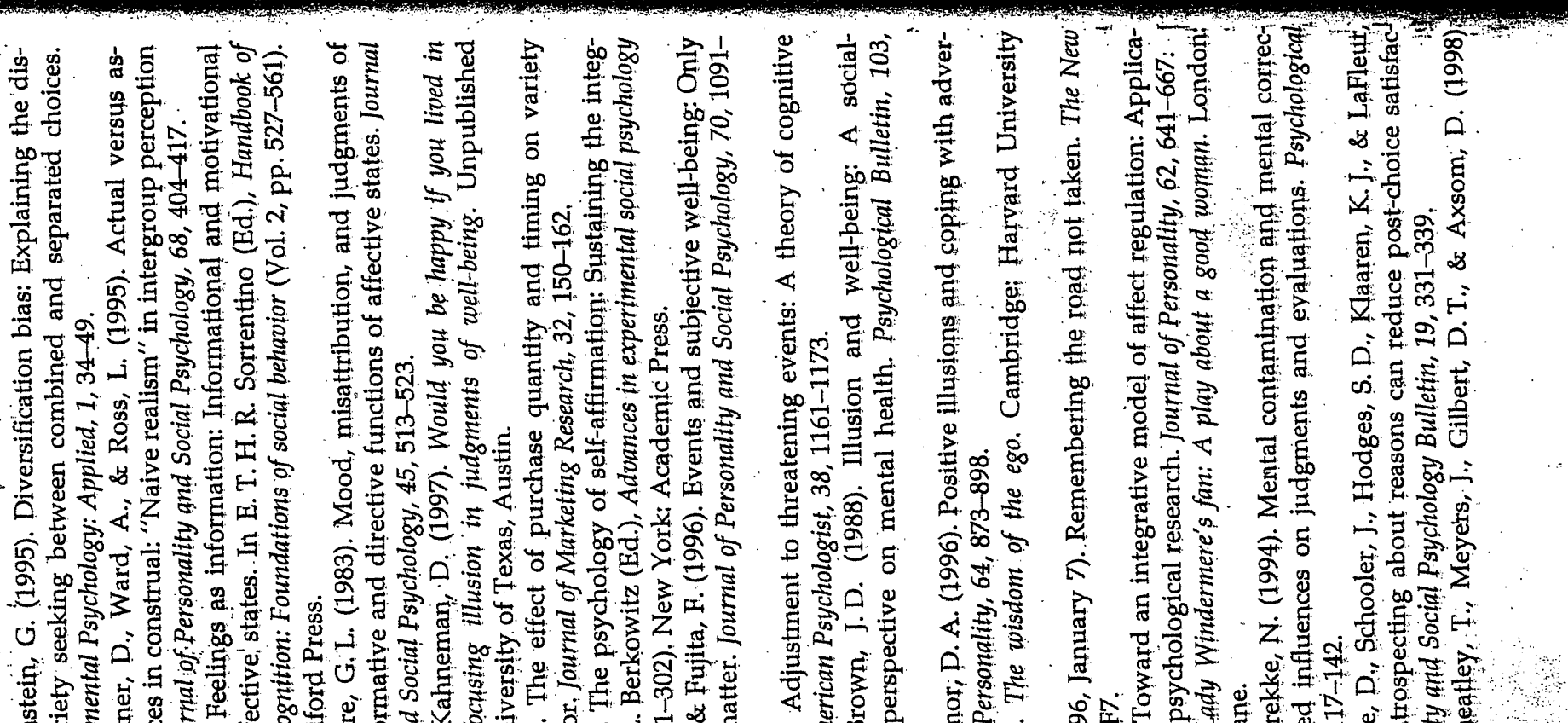

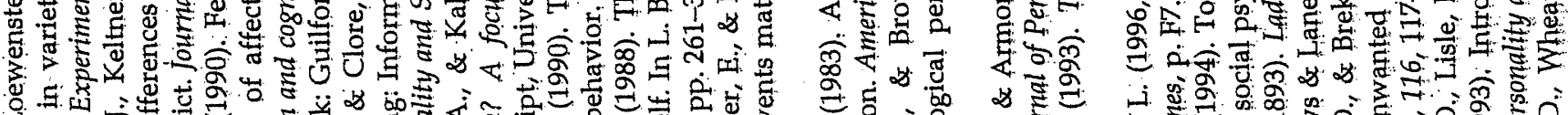

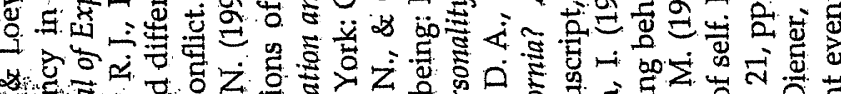

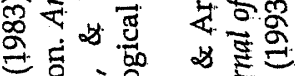

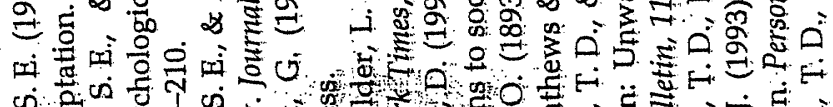

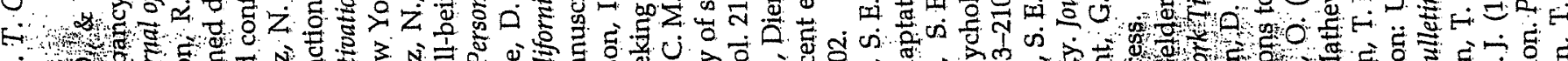

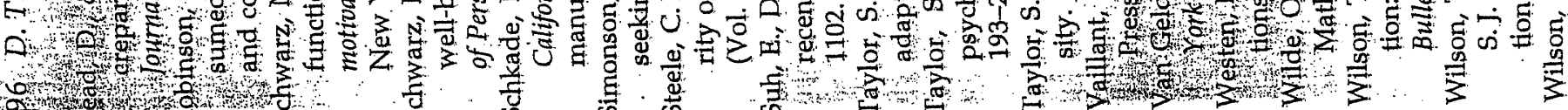



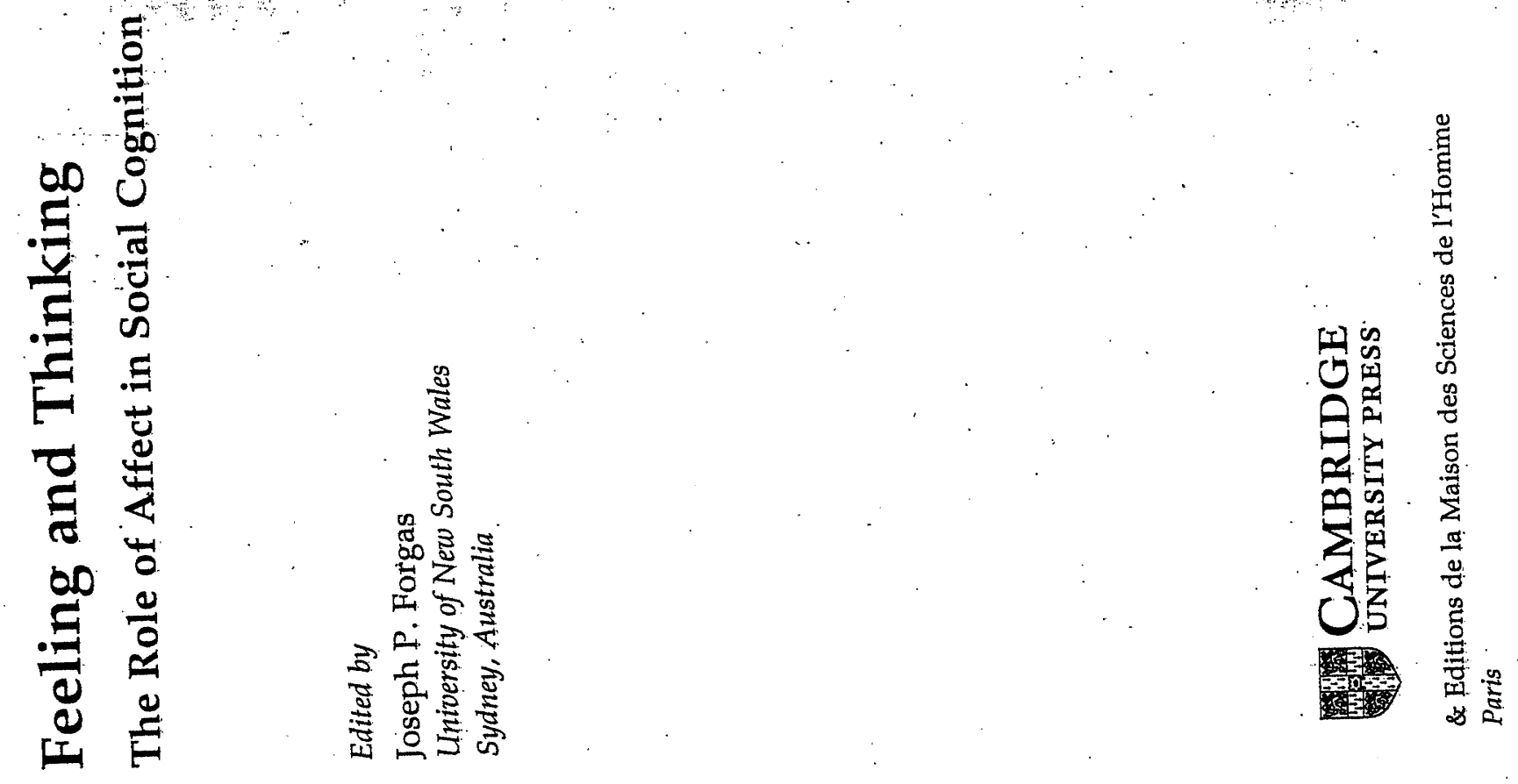